\title{
Enhancing Aromatic Foldamer Helix Dynamics to Probe Interactions with Protein Surfaces
}

\author{
Maëlle Vallade, ${ }^{[a]}$ Post Sai Reddy, ${ }^{[a]}$ Lucile Fischer, ${ }^{[a]}$ and Ivan Huc*[a,b]
}

Abstract: Dynamic helices that undergo exchange between $P$ and $M$ conformations can be used as sensors when their interactions with chiral substances results in a helix handedness bias. For instance, chiral induction in short helically folded aromatic oligoamides based on 8-amino-2-quinoline carboxylic acid $(Q)$ has been used to detect interactions with proteins and nucleic acids. However, the stability of these helices in water increases rapidly with oligomer length to the extent that helix dynamics become too slow for sensing applications. We have developed an approach to enhance the helix dynamics of these oligomers through the introduction of more flexible 6-aminomethyl-2-pyridinecarboxylic acid units $(P)$ while preserving helix integrity. A series of $P / Q$ hybrid oligoamides were synthesized and their rate of helix handedness inversion was evaluated by monitoring induced circular dichroism so as to define the requirements to bring kinetics in a practical range for sequences as long as fourteen units. Proof of principle was then brought by confining such sequences at the surface of carbonic anhydrase and showing that protein-mediated helix handedness induction occurs.

\section{Introduction}

Helical molecules are inherently chiral objects that may exist as right-handed $(P)$ or left-handed $(M)$ conformers. ${ }^{[1]}$ Helicity is termed dynamic when an equilibrium between $P$ and $M$ helices is allowed by a conformational reorganization of the molecule such as the propagation of a helix handedness inversion center. ${ }^{[2]}$ In contrast, rigid helices do not undergo helix handedness inversion. There has been great interest in helix dynamics because it can be biased under the effect of stereogenic centers either belonging to the helix backbone itself, or to chiral molecules that interact diastereoselectively with the helix and thus stabilize either $P$ or $M$ helicity. ${ }^{[1]}$ Helix handedness bias then becomes a strong marker of the presence of a particular chiral entity and can be used for sensing. ${ }^{[3]}$ Chiral sensing with dynamic helices exploits the fact that helical molecules generally have a strong chiral spectroscopic signature, e.g. intense circular dichroism (CD). In addition, the persistence of helix handedness over multiple helix turns that results from the integrity of a particular helical structure allows for some sort of amplification of chirality. ${ }^{[3,4]}$ For example, a chiral molecule that interacts at one end of a helix and that favors $P$ or $M$ helicity at that location may result in the whole helix to become $P$ or $M$ helical. ${ }^{[5,6]}$ This amplification also amounts to a sort of signal transduction: the

[a] Université de Bordeaux,

CNRS, Bordeaux Institut National Polytechnique, CBMN (UMR 5248), IECB,

2 rue Robert Escarpit, 33600 Pessac, France

URL: http://www.iecb.u-bordeaux.fr/teams/bise/

[b] Department of Pharmacy, Ludwig-Maximilians-Universität,

Butenandtstr. 5-13, 81377 München, Germany

E-mail: ivan.huc@cup.Imu.de

URL: https://huc.cup.uni-muenchen.de/ chiral information brought by the chiral molecule at one end of the helix can be read at the other end where handedness bias is also effective. ${ }^{[6]}$ When helix dynamics can be switched on and off upon changing solvent or temperature, chirality can be memorized. ${ }^{[7]}$ Helix handedness bias is then stable in time even after the source of chiral bias has been removed.

Our group has been exploring helix handedness bias in aromatic oligoamides ${ }^{[8]}$ derived from 8-amino-2-quinolinecarboxylic acid Q (Figure 1) bearing different proteinogenic side chains as a means to probe interactions with protein ${ }^{[9]}$ and nucleic acid ${ }^{[10]}$ surfaces. Proteins display chiral information at every L-amino acid, and also over longer distances through the twist of $\alpha$-helical and $ß$-sheet motifs. When a foldamer carrying proteinogenic side chains is confined at the surface of a protein, handedness bias indicates that a particular set of foldamer side chains engage in interactions with the protein. ${ }^{[11]}$ This approach has been successful to detect interactional patterns that were eventually deciphered by X-ray crystallography and that would have been hard to predict otherwise, including foldamer protein complexes with 2:2, 2:3 and 2:2:1 stoichiometry. ${ }^{[9]}$<smiles>[R]c1cc(C(C)=O)nc2c(NC)cccc12</smiles>

Q monomer

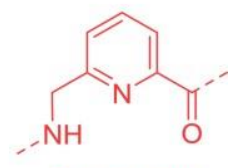

P monomer
Figure 1. General structures of $\mathbf{Q}$ and $\mathbf{P}$ monomers. $\mathbf{R}$ groups diverge from helices formed by $Q_{n}$ oligomers and determine their solubility.

The idea to use helices to recognize protein surfaces and as potential protein-protein interaction inhibitors stems from the extensive involvement of proteins' own a-helices at protein- 
protein interfaces. ${ }^{[12]}$ Thus, extensive efforts have been made to produce a-helix mimetics under the form of helical a-peptide analogues and homologues. ${ }^{[13]}$ Except for some nonhelical rodlike objects, ${ }^{[14]}$ these mimetics are generally chirally biased and thus not prone to sensing chirality at the protein surface. In addition, isolated $\alpha$-helices are not particularly stable, and their use to bind to a protein surface often requires some sort of stabilization through the use of helicity initiators ${ }^{[15,16]}$ or through the stapling of some side chains. ${ }^{[17]}$ In contrast, $Q_{n}$ helices show remarkable stability in water. ${ }^{[8 c, 18]}$ While this is an advantage in terms of structural integrity, it represents a disadvantage in terms of helix dynamics. Short $Q_{n}$ helical oligomers with $n \leq 5$ show reasonably fast dynamics with halflives of handedness inversion in water up to a few hours. ${ }^{\left[{ }^{[b]}\right.}$ But the handedness of longer sequences is essentially kinetically inert in water and thus not anymore useful to probe interactions with proteins. This limitation prevents screening of chiral interactions using long sequences and thus the possibility to cover a large surface area of a protein. To solve that problem, we have endeavored into deliberately engineering helix destabilization in $Q_{n}$ oligomers so as to enhance handedness dynamics even for long sequences. This approach contrasts with the efforts of the peptide chemistry community to stabilize ahelices and a-helix mimetics. ${ }^{[15-17,19]}$

Here, we report on the design of helical aromatic foldamer sequences in which flexible units $P$ (Figure 1 ) are introduced to enhance helix handedness inversion kinetics. We show that a sufficient number of $\mathrm{P}$ units allow for keeping helix handedness half-life of $P / Q$ hybrid oligomers within a practical experimental range for up to fourteen units (i.e. almost six full helix turns). The approach can in principle be extrapolated to even longer sequences. As a proof of concept, we have synthesized P/Q oligomers having up to 14 units, various side chains and an appended human carbonic anhydrase (HCAll) nanomolar ligand. Upon incubating the foldamers with HCA, the ligand binds to the protein and confines the foldamer to the protein surface. In some cases, handedness induction was detected by $\mathrm{CD}$ proving that helix handedness is dynamic and that stereoselective interactions take place between the foldamer and the protein.

\section{Results and Discussion}

\section{First Generation Foldamer Design and Synthesis}

$\mathrm{Q}_{\mathrm{n}}$ oligomers have been shown to adopt helical conformations in which five units span almost exactly two turns. ${ }^{[8]} \mathrm{A}$ top view of the helix is thus typically depicted as a five-pointed-star (Figure 2). $P$ units have also been reported previously. ${ }^{\left[{ }^{[0]}\right.}$ They possess the same $\delta$-peptidic inner rim as the Q units and thus bring the same contribution to helix curvature. However, the additional rotatable bonds associated with the benzylic methylene bring about flexibility. The effect is so strong that $P_{n}$ oligomers do not fold at all. ${ }^{[20 b]}$ However, when present, $Q$ units dominate folding and $(P Q)_{n}$ sequences $(n=4-7)^{[20 b]}$ and $\mathrm{Q}_{n} \mathrm{P}_{m} \mathrm{Q}_{n}$ sequences ${ }^{[20 a]}$ adopt canonical helical conformations. The balance between helical folding and fast helix dynamics was recently shown to allow for the passage of short $P / Q$ hybrid sequences through the ribosome exit tunnel. ${ }^{[20 c]}$

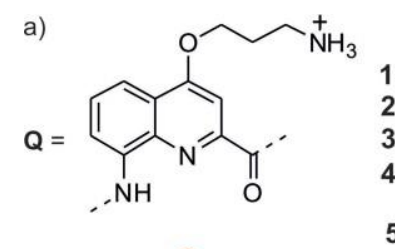

1: $\quad A c-Q P Q P Q Q-P h e$

2: $\quad$ Ac-PQQPQPQQ-Phe

3: $\quad$ Ac-PQPQQPQPQQ-Phe

4: $\quad$ Ac-QPQPQQPQPQQ-Phe

$\mathbf{P}=$

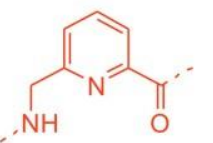

Ac-PQQPQQ-Phe

5:
6:

7: $\quad$ Ac-QPQPPQPQPQQ-Phe

8: Ac-QPQQPQPPQPQPQQ-Phe

b)

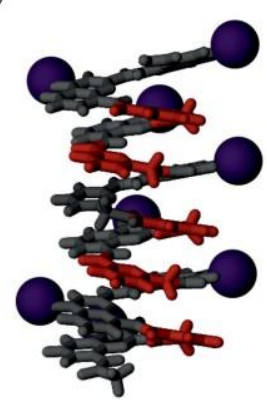

Figure 2. a) Sequences of $Q / P$ hybrid foldamers synthesized by SPS using $P$ and positively charged $\mathrm{Q}$ building blocks and a C-terminal L-phenylalanine. b) Top view and side view of the energy minimized model (force field MMFFs) and 5-pointed star representation of amphipathic hybrid $\mathrm{Q} / \mathrm{P}$ foldamer Ac-QPQQPQPPQPQPQQ. Units are counted from the C-terminus in the five-pointed star. Grey tube representation = quinoline backbone and methyl pyridine unit 7 (from C-terminus), red tube representation = methyl pyridine backbone other than unit 7 , purple balls = quinoline side chains .

Sequences 1-8 possess various combinations of $\mathrm{Q}$ and $\mathrm{P}$ monomers within sequences ranging from six to fourteen units (Figure 2). All are acetylated at their $\mathrm{N}$-terminus and possess a chiral phenylalanine at their $\mathrm{C}$-terminus for the purpose of helix handedness monitoring (see below). Water solubility is ensured by ornithine-like side chains at every $\mathrm{Q}$ monomer. The accumulation of charges is known to destabilize peptidic helices, but no such effect has been observed with aromatic helices so far. The organization of $P$ and $Q$ monomers in the sequence has been designed to introduce a certain degree of alternation, and also to preserve one face of the helix for interactions with a protein surface that could be mediated by varied side-chains at $Q$ units. ${ }^{[21]}$ Thus, in oligomers $\mathbf{1 - 4}$, two fifth of the monomers are $P$ units and they are all located on the same face of the helix. $P$ units are never found in consecutive positions. In 7 and $\mathbf{8}$, the same pattern has been elongated and an additional $P$ unit has been introduced to create a PP segment to enhance flexibility. Sequences $\mathbf{5}$ and $\mathbf{6}$ are positional variants of $\mathbf{1}$ and $\mathbf{2}$, respectively.

Another important design feature is the presence of an Lphenylalanine at the $\mathrm{C}$-terminus of all sequences. This chiral residue has been shown to bias helix handedness of $Q_{n}$ oligomers in polar solvents such as DMSO (diastereomeric excess of $40 \%$ ) in which helix dynamics are relatively fast. ${ }^{[22]}$ In contrast, handedness induction by the same residue in chloroform is 
weak. ${ }^{[8 a]}$ In this study, we took advantage of solvent dependence of helix sense bias to monitor the rate of helix handedness inversion (see below). In order to keep the extent of helix handedness bias strong enough and constant throughout oligomers 1-8, all sequences possess the same four units at their C-terminus and, in particular have two $Q$ units at the end to limit fraying that could arise from $P$ units.

For the preparation of these sequences, Fmoc-acid building blocks were activated as acid chlorides for coupling on aromatic amines and sequences were prepared via microwave-assisted solid phase synthesis on Wang resin as described previously. ${ }^{[20 b, 23]}$ Acid chloride 17 bearing the protected ornithinelike side chain has been described previously. ${ }^{[20 \mathrm{~b}]}$ Acid chloride 16 (Scheme 1) is a new compound prepared from its Boc precursor $13,{ }^{[20 a]}$ which was synthesized from commercially available starting material $\mathbf{9}$. To prevent acylation of the pyridine nitrogen, this acid chloride worked best if used as a hydrochloride salt. Acid chlorides or classical HBTU activation work for couplings to aliphatic amines. Side chain deprotection and cleavage from the resin were carried out in 95:2.5:2.5 TFA/ $\mathrm{Pr}_{3} \mathrm{SiH} / \mathrm{H}_{2} \mathrm{O}$ ( $\left.\mathrm{vol} / \mathrm{vol} / \mathrm{vol}\right)$. Crude oligomers were typically obtained in 48-94\% purity. Sequences were purified by reversedphase HPLC and obtained in 8-70\% yield from initial Wang resin loadings.<smiles>COC(=O)C#CC(O)c1cccc(C(=O)OC)n1</smiles>
9 10<smiles>CC(=O)OCc1cccc(C(N)C#CC(=O)OCc2ccccc2)n1</smiles>

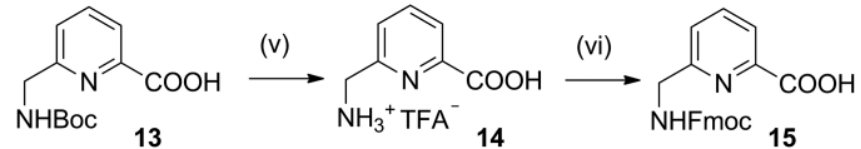

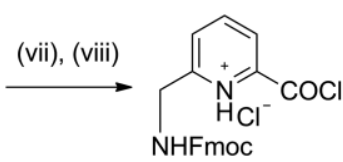
16

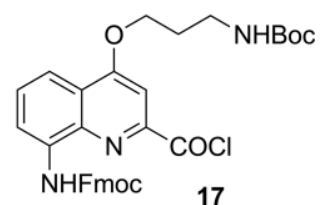

Scheme 1. Activated $\mathbf{P}$ and $\mathbf{Q}$ monomers for SPS. Reagents and conditions: (i) $\mathrm{NaBH}_{4}, \mathrm{CH}_{2} \mathrm{Cl}_{2} / \mathrm{MeOH}, 0{ }^{\circ} \mathrm{C}$ to room temp. (ii) $\mathrm{PPh}_{3}, \mathrm{CBr}_{4}, \mathrm{DMF}, \mathrm{NaN}_{3}$, room temp. (iii) (Boc) ${ }_{2} \mathrm{O}, \mathrm{H}_{2}, \mathrm{Pd} / \mathrm{C}$, THF, room temp. (iv) $\mathrm{LiOH} \mathrm{H}_{2} \mathrm{O}, \mathrm{THF} / \mathrm{H}_{2} \mathrm{O}$, room temp. (v) TFA $/ \mathrm{CH}_{2} \mathrm{Cl}_{2}$ room temp. (vi) $\mathrm{FmocCl}, \mathrm{NaHCO}_{3}$, 1,4-dioxane $/ \mathrm{H}_{2} \mathrm{O}$, room temp. (vii) $\mathrm{HCl}, \mathrm{MeOH}$. (viii) Ghosez reagent, $\mathrm{CH}_{2} \mathrm{Cl}_{2}$.

\section{Kinetics of Helix Handedness Inversion}

Some qualitative information about the kinetics of helix handedness inversion was obtained by ${ }^{1} \mathrm{H}$ NMR spectroscopy and from HPLC profiles. For example, the NMR spectra of the shortest sequences $\mathbf{1}$ and $\mathbf{5}$ showed a single set of signals which was attributed to a rapid exchange of $P$ and $M$ helices on the NMR timescale (see supporting information). In contrast, two sets of signals could be observed on the spectra of longer sequences. Similarly, the HPLC profile of some of the longest sequences showed two peaks assigned to slow exchange on the chromatographic timescale. The presence of a single peak may result from faster kinetics but also from peak overlap when diastereomeric $P$ and $M$ helices have the same retention time.

Quantitative assessment of the rates of helix handedness inversion was carried out using $\mathrm{CD}$. All compounds were well soluble in an aqueous $12.5 \mathrm{~m}_{\mathrm{M}} \mathrm{NH}_{4} \mathrm{OAc}$ buffer at $\mathrm{pH}$ 7.2. This volatile buffer was selected to facilitate recovery of the foldamers by freeze-drying. It was first verified that handedness induction does take place in this medium: a positive $C D$ band near $375 \mathrm{~nm}$ is indicative of a preferred right-handed helicity for the L-Phe-functionalized oligomers. It was then noted that no handedness bias is observed in TFA, presumably as a consequence of the loss of helical conformation upon protonation of $P$ units. ${ }^{[24]}$ Thus, upon first incubating an oligomer in TFA, evaporating the solvent, and then dissolving it in the aqueous buffer, a CD signal was observed to build up as handedness bias takes place (Figure 3a). The appearance of the $C D$ band was monitored at $22{ }^{\circ} \mathrm{C}$ and $37{ }^{\circ} \mathrm{C}$ and fitted to a first order kinetic model (Figure $3 \mathrm{~b}$ ) to extract rate constants and half-lives of handedness inversion (Table 1). Curiously, a weak negative band was consistently observed immediately after dissolving the compounds, before the positive $C D$ band builds up (see the $\mathrm{CD}$ spectra of 6 at $22^{\circ} \mathrm{C}$ and 3 and 4 at $37^{\circ} \mathrm{C}$ ). The effect of ${ }_{\mathrm{L}}$-Phe on helical folding from an unfolded state might somewhat kinetically favor an $M$ helix even though the $P$ helix is thermodynamically more stable and quickly becomes the dominant species.

The kinetics of helix handedness inversion were quite variable. Consistent with their NMR spectra, the buildup of $P$ helicity in hexamers $\mathbf{1}$ and $\mathbf{5}$ was too fast to monitor: equilibrium was reached from the first spectrum. This contrasts much with the extremely slow kinetics of racemization of a $Q_{6}$ sequence in water which are too slow to monitor and reflects that the desired effect of $P$ units is at play. Kinetics were also too fast to monitor for octamer 2 but were significantly slower for its analogue $\mathbf{6}\left(t_{1 / 2}=11.5 \mathrm{~h}\right.$ at $\left.22{ }^{\circ} \mathrm{C}\right)$. The difference between 2 and 6 reflects a dependence of the kinetics on the arrangement of $P$ and $Q$ units in the sequence. Since kinetics were faster for $\mathbf{2}$, we considered extensions in this series only. Thus, half-lives were of the order of a few hours for decamer 3 . However, the addition of a single $Q$ residue in undecamer 4 resulted in a strong stabilization. Kinetics became too slow to monitor at $22{ }^{\circ} \mathrm{C}$ but remained relatively fast at $37{ }^{\circ} \mathrm{C}\left(t_{1 / 2}=1.6 \mathrm{~h}\right)$. The sharp dependence of these kinetics on sequence length and on temperature hint at significant cooperativity of folding in aqueous medium. In any case, it pointed to the consistent stabilization of the (PQPQQ) pentameric repeat motif upon its elongation and to the impossibility to reach fast handedness inversion kinetics for longer sequences in which only two fifth of the monomers are $\mathrm{P}$ units.

Undecamer 7 was thus introduced. It corresponds to the sequence of $\mathbf{4}$ in which a $\mathrm{Q} \rightarrow \mathrm{P}$ mutation has been implemented. Indeed, the rates of handedness inversion of 7 were again within a range compatible with the laboratory timescale and 

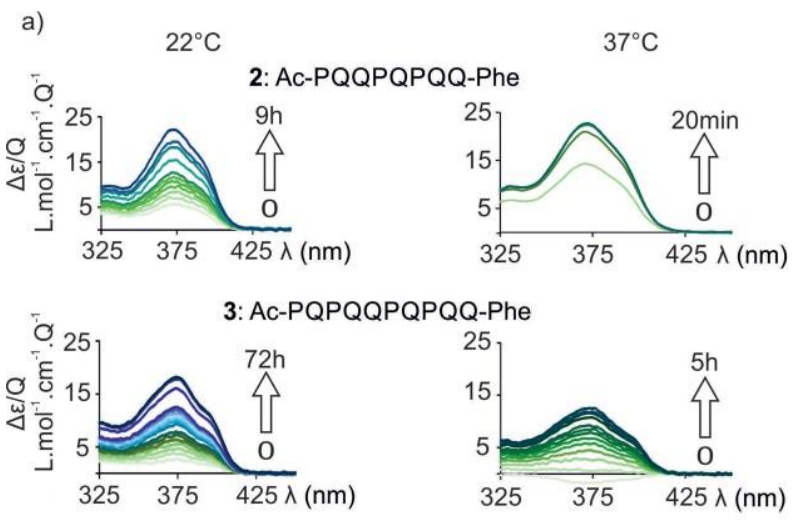

Table 1. Rate constants and half-life times of helical handedness inversion for compounds 1 to 8 .

\begin{tabular}{lllll}
\hline Compounds & $k_{1}\left[\mathrm{~h}^{-1}\right]$ & \multicolumn{3}{l}{$t_{1 / 2}[\mathrm{~h}]$} \\
\hline $\mathbf{1}$ & $T=22{ }^{\circ} \mathrm{C}$ & $T=37{ }^{\circ} \mathrm{C}$ & $T=22{ }^{\circ} \mathrm{C}$ & $T=37{ }^{\circ} \mathrm{C}$ \\
$\mathbf{2}$ & {$[\mathrm{f}]$} & {$[\mathrm{f}]$} & {$[\mathrm{f}]$} & {$[\mathrm{f}]$} \\
$\mathbf{3}$ & {$[\mathrm{f}]$} & {$[\mathrm{f}]$} & {$[\mathrm{f}]$} & {$[\mathrm{f}]$} \\
$\mathbf{4}$ & 0.089 & 0.65 & 7.8 & 1.1 \\
$\mathbf{5}$ & {$[\mathrm{s}]$} & 0.43 & {$[\mathrm{~s}]$} & 1.6 \\
$\mathbf{6}$ & {$[\mathrm{f}]$} & {$[\mathrm{f}]$} & {$[\mathrm{f}]$} & {$[\mathrm{f}]$} \\
$\mathbf{7}$ & 0.06 & {$[\mathrm{f}]$} & 11.5 & {$[\mathrm{f}]$} \\
$\mathbf{8}$ & 0.44 & {$[\mathrm{f}]$} & 1.5 & {$[\mathrm{f}]$} \\
\hline
\end{tabular}

[f] Kinetics were too fast to monitor. [s] Kinetics were too slow to monitor.

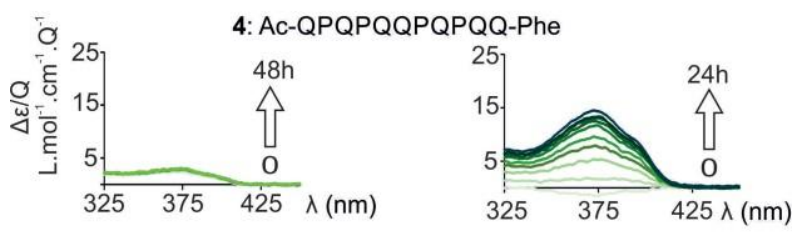

sequences were needed, one can speculate that the introduction of a proper number of $\mathrm{P}$ units would also lead to sufficiently fast rates of handedness induction.

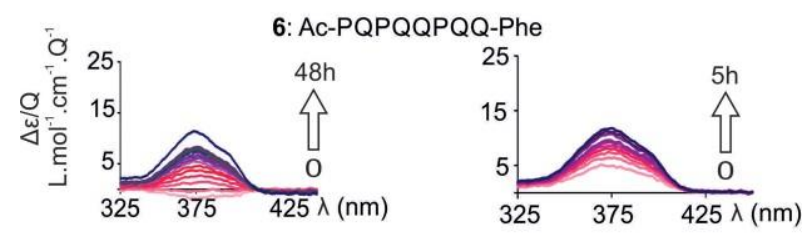

\section{Application to Foldamers Confined at the Surface of a Protein}

Foldamers 18-20 (Figure 4a-c) bearing varied side chains were synthesized using solid phase synthesis. These foldamers possess an appended arylsulfonamide nanomolar ligand of the human carbonic anhydrase II (HCA) active site. Upon binding of the ligand to HCA, the foldamer is therefore confined at the protein surface. As in earlier studies, the set of side chains in 18-20 was set without any particular bias. ${ }^{[9 a]}$ Interactions with the protein were not predicted. All three sequences comply with the design principles shown in Figure $2 \mathrm{~b}$ : side chains have been confined on one face of the helix, whereas $P$ units occupy the other face. Circular dichroism spectra of the ligand-mediated foldamer-HCA complexes were measured at different $\mathrm{pH}$ conditions in a phosphate buffer. This buffer was used instead of ammonium acetate as above for consistency with early studies with HCA. ${ }^{[9 a-c]}$ Two $\mathrm{pH}$ values were selected because it was observed before that foldamer-protein interactions, and thus protein-mediated helix handedness induction, may vary with

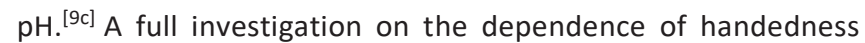
induction on $\mathrm{pH}$, salt concentration and nature of buffer was not carried out. The CD spectra revealed right- or left-handed helix induction of some foldamers by the protein. In the case of HCA-18, CD at pH 7.4 in a phosphate buffer shows a negative band in the quinoline absorption region characteristic of $M$ helicity whereas the $\mathrm{CD}$ at $\mathrm{pH} 4.6$ in the same buffer shows a positive band in the quinoline absorption region characteristic of $P$ helicity (Figure $4 \mathrm{~d}$ ). This variation indicates a substantial change in foldamer-protein interactions as the charge state of the protein and foldamer side chains vary. Yet no precise assignment is possible in the absence of structural elucidation. In contrast to HCA-18, HCA-19 showed positive CD under both $\mathrm{pH}$ 4.6 and 7.4 conditions (Figure $4 d$ ). The CD of HCA- 20 complex had very low intensity at $\mathrm{pH} 7.4$ indicating either very weak foldamer protein interactions, or equal interactions of the $P$ and $M$ helices. A positive $\mathrm{CD}$ band was instead observed at $\mathrm{pH} 4.6$. Altogether, these results confirm that $\mathrm{Q} / \mathrm{P}$ hybrid oligomers possess sufficiently fast helix dynamics for handedness induction

this held true also for tetradecamer $\mathbf{8}$. Because of the significant size of the latter, no longer sequence was prepared. If such
Figure 3. a) Circular Dichroism (CD) spectra of compounds 2-4 and 6 corded at $22{ }^{\circ} \mathrm{C}$ (left) and $37{ }^{\circ} \mathrm{C}$ (right) at $35 \mu_{\mathrm{M}}$ in a buffer at $\mathrm{pH} 7.2(12.5 \mathrm{mM}$ ple and monitored over time. The time range corresponds to the first and last spectra shown. The spectra are normalized per $\mathrm{Q}$ monomer. b) Curv the kinetics of racemization fitted to a first order model, for compounds 3 and 6 at $22{ }^{\circ} \mathrm{C}$ and compounds 3 and 4 at $37^{\circ} \mathrm{C}$. 
to take place and thus that they can be used for detecting interactions between foldamers and protein surfaces.

a)<smiles>[X]c1cccc(CNC(=O)c2ccc(S(=O)(=O)O[Na])cc2)c1</smiles>

b)

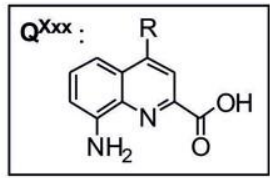

P :

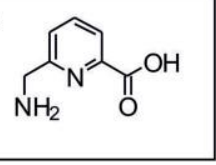

$\mathrm{Q}^{\mathrm{Hyd}}: \mathrm{R}=\mathrm{K}_{\mathrm{OH}}$

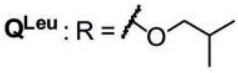

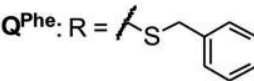

$Q^{\text {Orn: }} \mathrm{R}=$ 人 $\widehat{\mathrm{NH}}_{2}$

$Q^{\text {Asp: }: \mathrm{R}}=\widehat{\mathrm{O}}_{\mathrm{O}} \mathrm{CO}_{2} \mathrm{H}$

$\mathrm{Q}^{\mathrm{sAsp}}: \mathrm{R}=\propto \mathrm{CO}_{2} \mathrm{H}$

c) 18: Inh- $Q^{\text {sAsp }}-P_{-}-Q^{\text {Leu }}-Q^{\text {Orn }}-P_{-} Q^{A s p}-P_{-}-Q^{\text {Orn }}-Q^{H y d}$

19: Inh-Q $Q^{O m}-P_{-}-Q^{\text {Phe }}{ }_{-} Q^{\text {SAsp }}-P_{-}-Q^{\text {Leu }}-P-P-Q^{O r n}-P-Q^{A s p}-P-Q^{O m}-Q^{H y d}$

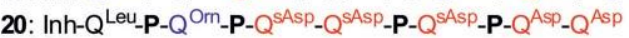

d)

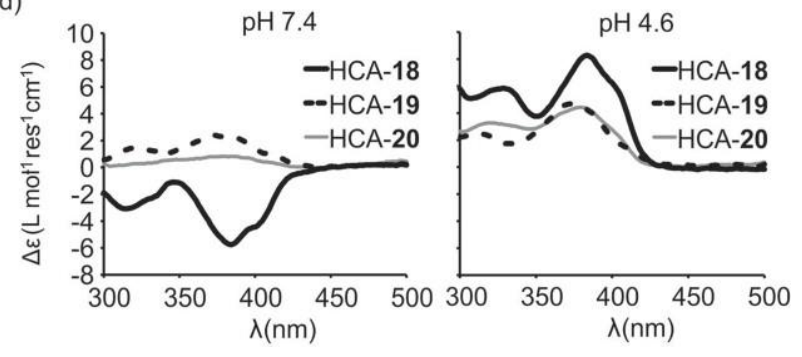

Figure 4. Foldamer-HCA interactions. a) Formula of HCA ligand. b) Foldamers with variety of side chains; hydrophobic (black), polar (green), positively charged (purple), negatively charged (red) residues. c) Synthesized foldamers 18-20. d) CD spectra of HCA-18, HCA-19 and HCA-20 complexes after equilibration at different $\mathrm{pH}$ conditions in phosphate buffer at $25^{\circ} \mathrm{C}$.

\section{Conclusions}

We have demonstrated that $P / Q$ hybrid sequences possessing $P$ units at certain positions undergo helix handedness inversion fast enough for the kinetics to remain in a practical range of hours or less. This has been validated for sequences up to fourteen units of these $\delta$-amino acids, i.e. the equivalent of a 28 mer peptide. Presumably, the results can be extrapolated and applied to longer sequences. Furthermore, this has been made possible while preserving a sort of amphipathic nature of the helix. All $P$ units have been confined on one face of the helix to allow for $Q$ units equipped with proteinogenic side chains to be clustered on the opposite face in such a way that they can interact with, and sense the chirality of, for example, a protein or a nucleic acid surface. Where this amphipathicity is not required, or should proper functionalities be available on $P$ units as well, different sequence arrangements of $P$ and $Q$ monomers than those described here should also bring sufficiently fast helix handedness dynamics. We also brought proof of concept that long $P / Q$ hybrid helices (up to fourteen units) can serve to detect stereoselective interactions between the foldamer helix and a protein surface, here human carbonic anhydrase II. This was achieved by confining the foldamer at the protein surface and observing induced $C D$ in the foldamer chromophore absorption region. Our results hint at foldamerprotein interactions possibly involving large surface areas of the protein. These interactions are currently the object of structural investigations that will be reported in due course.

\section{Experimental Section}

General: Low loading Wang resin was purchased from Novabiochem. Anhydrous $\mathrm{N}, \mathrm{N}$-dimethylformamide (DMF) and 1-chloro- $\mathrm{N}, \mathrm{N}, 2-$ trimethylpropenylamine (Ghosez reagent) were purchased from Sigma Aldrich. Chloroform, triethylamine and $\mathrm{N}, \mathrm{N}$-diisopropylethylamine (DIEA) were distilled from calcium hydride. Analytical grade organic solvents were used for solid phase synthesis. Dry organic solvents for solution and solid phase synthesis ( $\mathrm{THF}, \mathrm{CH}_{2} \mathrm{Cl}_{2}$, Toluene) were dispensed from a solvent purification system that passes solvents through packed columns of dry neutral alumina. MilliQ water was delivered from a PureLab Prima 7/15/20 system. RPHPLC quality acetonitrile $\left(\mathrm{CH}_{3} \mathrm{CN}\right)$ and MilliQ water were used for RPHPLC analysis and purification. Reactions requiring anhydrous conditions were performed under nitrogen. ${ }^{1} \mathrm{H}$ NMR spectra were measured at $300 \mathrm{MHz}$ or $400 \mathrm{MHz}$ and ${ }^{13} \mathrm{C}$ NMR spectra were measured at 75 or $100 \mathrm{MHz}$ on Bruker-Avance spectrometers. Chemical shifts are reported in $\mathrm{ppm}$ and are calibrated against residual solvent signals of $\mathrm{CDCl}_{3}(\delta=7.26,77.2)$, $\left[\mathrm{D}_{6}\right] \mathrm{DMSO}(\delta=2.50,39.4)$, or to the reference signal of TMS $\left(\delta=0.00 \mathrm{ppm}\right.$ for $\left.{ }^{1} \mathrm{H}\right)$ from $10 \mu_{\mathrm{M}} 3$ (trimethylsilyl)-1-propanesulfonic acid sodium salt in $\mathrm{H}_{2} \mathrm{O} / \mathrm{D}_{2} \mathrm{O}$ (9:1, $\mathrm{vol} / \mathrm{vol}$ ). Signals were abbreviated as s, singlet; brs, broad singlet; $d$, doublet; $t$, triplet; $q$, quartet; $m$, multiplet. Silica gel chromatography were performed using Merck silica gel Si 60. Thin layer chromatography were performed using Merck silica gel Si 60 F254 plates and observed under UV light (254 and $365 \mathrm{~nm}$ ). SPS was carried out manually at atmospheric pressure using a CEM Discover microwave oven and SPS station in the proprietary reactor vessels. The temperature of microwave-assisted reactions was controlled by an optical fiber probe internal to the reaction mixture. RP-HPLC analysis were performed using a Macherey-Nagel Nucleodur C18 HTEC column $(4.6 \times 100 \mathrm{~mm}, 3 \mu \mathrm{m})$ at $1 \mathrm{~mL} / \mathrm{min}$ with running solvents: Milli-Q water containing 0.1 vol.-\%/vol TFA (solvent $\mathrm{A}$ ), $\mathrm{CH}_{3} \mathrm{CN}$ containing 0.1 vol.-\%/vol TFA (solvent $B$ ). Monitoring by UV detection was carried out at $214 \mathrm{~nm}, 254 \mathrm{~nm}$ and $300 \mathrm{~nm}$. Purification of oligoamides was performed at $4 \mathrm{~mL} / \mathrm{min}$ on a C18 column $(21 \mathrm{~mm} \times 125 \mathrm{~mm}$, $5 \mu \mathrm{m})$ by semi-preparative RP-HPLC. The mobile phases were the same as for the analytic system. Monitoring by UV detection was carried out at $254 \mathrm{~nm}$ and $300 \mathrm{~nm}$ using a diode array detector. High resolution electrospray ionization time-of-flight (ESI-TOF) mass spectra were measured in the positive ion mode on a Waters/Micromass Q-Tof Ultima. Melting points of either recrystallized solids or amorphous powders were measured in open capillary tubes, using a digital Büchi B-540 melting point apparatus. CD spectra were recorded on a Jasco J-815 Circular Dichroism spectrometer using quartz cells of 1,2 , or $10 \mathrm{~mm}$ optical path length. Scans were measured over a wavelength range of $300-500 \mathrm{~nm}$, with a response time of $0.5 \mathrm{~s}$ and a scanning speed of $50 \mathrm{~nm} \mathrm{~min}$.

Synthesis of Compound 10: Dimethyl pyridine-2,6-dicarboxylate 9 (60.5 g, $310 \mathrm{mmol}$ ) was dissolved in $1 \mathrm{~L}$ of a $1: 1 \mathrm{CH}_{2} \mathrm{Cl}_{2} / \mathrm{MeOH}$ (vol/ vol) mixture and placed at $0{ }^{\circ} \mathrm{C}$ under $\mathrm{N}_{2} . \mathrm{NaBH}_{4}(14.07 \mathrm{~g}, 372 \mathrm{mmol}$, 1.2 equiv.) was added portion wise over $10 \mathrm{~min}$ and the reaction 
mixture was stirred $30 \mathrm{~min}$ at $0{ }^{\circ} \mathrm{C}$ then $40 \mathrm{~min}$ at $25{ }^{\circ} \mathrm{C}$. Solvents were removed under reduced pressure and a $5 \%$ citric acid solution was added carefully to reach $\mathrm{pH} 4-5$. The aqueous layer was extracted with $\mathrm{CH}_{2} \mathrm{Cl}_{2} / \mathrm{MeOH}(8: 2 \mathrm{vol} / \mathrm{vol})$. The organic phase was dried with $\mathrm{MgSO}_{4}$, filtered and the solvents evaporated. The residue was then dissolved in a minimum volume of $\mathrm{CH}_{2} \mathrm{Cl}_{2} / \mathrm{MeOH}$ (8:2 vol/ vol) and kept overnight at room temperature to afford prismshaped crystals of compound 10 . The crystals were filtered off and the filtrate was concentrated and crystallization repeated several times. At last, the filtrate was evaporated to dryness and the residue was purified by column chromatography. The combined crops yielded 10 as a white solid (30.31 g, $58.5 \%$ ). ${ }^{1} \mathrm{H}$ NMR $(300 \mathrm{MHz}$, $\left.\mathrm{CDCl}_{3}\right): \delta=8.04(\mathrm{~d}, J=7.7 \mathrm{~Hz}, 1 \mathrm{H}), 7.85(\mathrm{t}, J=7.8 \mathrm{~Hz}, 1 \mathrm{H}), 7.52(\mathrm{~d}$, $J=7.8 \mathrm{~Hz}, 1 \mathrm{H}), 4.86(\mathrm{~d}, J=5.3 \mathrm{~Hz}, 2 \mathrm{H}), 4.00(\mathrm{~s}, 3 \mathrm{H}), 3.32(\mathrm{t}, J=$ $5.4 \mathrm{~Hz}, 1 \mathrm{H}) \mathrm{ppm} .{ }^{13} \mathrm{C} \mathrm{NMR}\left(75 \mathrm{MHz}, \mathrm{CDCl}_{3}\right): \delta=165.70,160.30$, 147.19, 137.83, 124.14, 123.98, 64.74, $53.01 \mathrm{ppm}$. HRMS $\left(\mathrm{ESI}^{+}\right): \mathrm{m} / \mathrm{z}$ calcd. for $\mathrm{C}_{8} \mathrm{H}_{10} \mathrm{NO}_{3}[\mathrm{M}+\mathrm{H}]^{+}: 168.0655$ found 168.0655 . M.p. 89.5$91.5^{\circ} \mathrm{C}$.

Synthesis of Compound 11: Compound 10 (29 g, $173 \mathrm{mmol}$ ), $\mathrm{PPh}_{3}$ (54.6 g, 208 mmol, 1.5 equiv.) and $\mathrm{CBr}_{4}$ (69.1 g, $208 \mathrm{mmol}, 1.5$ equiv.) were added in that order to stirred dry DMF $(30 \mathrm{~mL})$ under $\mathrm{N}_{2}$. The reaction mixture was stirred $2 \mathrm{~h}$ at $25^{\circ} \mathrm{C}$. $\mathrm{NaN}_{3}(28.2 \mathrm{~g}, 434 \mathrm{mmol}$, 2.5 equiv.) was added in one portion and the resulting mixture was stirred at $25{ }^{\circ} \mathrm{C}$ overnight. $\mathrm{Et}_{2} \mathrm{O}$ and $\mathrm{H}_{2} \mathrm{O}$ were added and the aqueous layer was extracted with $\mathrm{Et}_{2} \mathrm{O}$. The combined organic layers were dried with $\mathrm{MgSO}_{4}$, filtered and the solvents evaporated. The residue was then purified by column chromatography (1:0 to $1: 1$ cyclohexane/EtOAc vol/vol) to yield compound 11 as a brown oil (29 g, $87 \%$ ). $\left.{ }^{1} \mathrm{H} \mathrm{NMR} \mathrm{(300} \mathrm{MHz,} \mathrm{CDCl}_{3}\right): \delta=8.12-8.06(\mathrm{~m}, 1 \mathrm{H}), 7.90$ $(\mathrm{t}, J=7.8 \mathrm{~Hz}, 1 \mathrm{H}), 7.63-7.57(\mathrm{~m}, 1 \mathrm{H}), 4.65(\mathrm{~s}, 2 \mathrm{H}), 4.02(\mathrm{~s}, 3 \mathrm{H})$ ppm. ${ }^{13} \mathrm{C} \mathrm{NMR}\left(75 \mathrm{MHz}, \mathrm{CDCl}_{3}\right): \delta=164.88,155.95,147.36,137.73$, 124.74, 123.87, 54.96, 52.47 ppm. HRMS $\left(\mathrm{ESI}^{+}\right): \mathrm{m} / \mathrm{z}$ calcd. for $\mathrm{C}_{8} \mathrm{H}_{9} \mathrm{~N}_{4} \mathrm{O}_{2}[\mathrm{M}+\mathrm{H}]^{+}: 193.0720$ found 193.0720 .

Synthesis of Compound 12: Compound 11 (18.4 g, $96 \mathrm{mmol})$ was dissolved in dry THF $(180 \mathrm{~mL})$ and put under $\mathrm{N}_{2}$. Boc ${ }_{2} \mathrm{O}(52.2 \mathrm{~g}$, $240 \mathrm{mmol}, 2.5$ equiv.) and $\mathrm{Pd} / \mathrm{C}(1.9 \mathrm{~g}, 10 \%$ by mass) were added in one portion to the mixture which was then placed under hydrogen atmosphere (H-PARR, 5 bar). The resulting mixture was stirred at room temperature for $2 \mathrm{~d}$ and then filtered through Celite ${ }^{\circledR}$ and the solvents evaporated. The residue was then purified by column chromatography (1:0 to 7:3 DCM/EtOAc vol/vol) to yield compound 12 as a yellow oil $(22.5 \mathrm{~g}, 88 \%) .{ }^{1} \mathrm{H} \mathrm{NMR}\left(300 \mathrm{MHz}, \mathrm{CDCl}_{3}\right): \delta=8.02$ $(\mathrm{d}, J=7.7 \mathrm{~Hz}, 1 \mathrm{H}), 7.82(\mathrm{t}, J=7.8 \mathrm{~Hz}, 1 \mathrm{H}), 7.51(\mathrm{~d}, J=7.8 \mathrm{~Hz}, 1 \mathrm{H})$, $5.44(\mathrm{~s}, 1 \mathrm{H}), 4.53(\mathrm{~d}, J=5.9 \mathrm{~Hz}, 2 \mathrm{H}), 4.00(\mathrm{~s}, 3 \mathrm{H}), 1.46(\mathrm{~s}, 9 \mathrm{H}) \mathrm{ppm}$. ${ }^{13} \mathrm{CNMR}\left(75 \mathrm{MHz}, \mathrm{CDCl}_{3}\right): \delta=165.58,158.76,156.01,147.37,137.67$, 125.11, 123.72, 79.62, 52.82, 45.95, $28.35 \mathrm{ppm}$. HRMS $\left(\mathrm{ESI}^{+}\right): \mathrm{m} / \mathrm{z}$ calcd. for $\mathrm{C}_{13} \mathrm{H}_{19} \mathrm{~N}_{2} \mathrm{O}_{4}[\mathrm{M}+\mathrm{H}]^{+}: 267.1339$ found 267.1339.

Synthesis of Compound 13: Compound 12 (22.4 g, $84 \mathrm{mmol})$ was solubilized in THF $(500 \mathrm{~mL})$. Water $(100 \mathrm{~mL})$ was added. $\mathrm{LiOH} \mathrm{H}_{2} \mathrm{O}$ (5.3 g, $126 \mathrm{mmol}, 1.5$ equiv.) was added in one portion. The reaction mixture was stirred $1 \mathrm{~h}$ at $25^{\circ} \mathrm{C}$. Aqueous $\mathrm{HCl}(1 \mathrm{~m})$ was then added to reach $\mathrm{pH} 3-4$. The product precipitated and was filtered, washed with water, toluene and then dried. The filtrate also contained some product, so it was extracted with $\mathrm{CH}_{2} \mathrm{Cl}_{2}$. The combined organic layers were washed with brine, dried with $\mathrm{MgSO}_{4}$, filtered and the solvents evaporated. A white solid was obtained (18.7 g, $88 \%) .{ }^{1} \mathrm{H}$ NMR $\left(300 \mathrm{MHz}, \mathrm{CDCl}_{3}\right): \delta=8.14(\mathrm{~d}, J=7.6 \mathrm{~Hz}, 1 \mathrm{H}), 7.94(\mathrm{t}, \mathrm{J}=$ $7.7 \mathrm{~Hz}, 1 \mathrm{H}), 7.59$ (d, J = 7.9 Hz, $1 \mathrm{H}), 5.23(\mathrm{~s}, 1 \mathrm{H}), 4.51(\mathrm{~d}, J=6.1 \mathrm{~Hz}$, $2 \mathrm{H}), 3.49(\mathrm{~s}, 1 \mathrm{H}), 1.47(\mathrm{~s}, 9 \mathrm{H}) \mathrm{ppm} .{ }^{13} \mathrm{C} \mathrm{NMR}\left(75 \mathrm{MHz}, \mathrm{CDCl}_{3}\right): \delta=$ $165.85,158.05,156.26,146.20,138.76,125.70,123.00,79.90,45.46$, $28.33 \mathrm{ppm}$. HRMS $\left(\mathrm{ESI}^{+}\right): \mathrm{m} / \mathrm{z}$ calcd. for $\mathrm{C}_{12} \mathrm{H}_{17} \mathrm{~N}_{2} \mathrm{O}_{4}[\mathrm{M}+\mathrm{H}]^{+}$: 253.1183 found 253.1181 .
Synthesis of Compound 14: Compound 13 (18.6 g, $73.8 \mathrm{mmol})$ was suspended in $\mathrm{CH}_{2} \mathrm{Cl}_{2}(90 \mathrm{~mL})$. TFA $(30 \mathrm{~mL})$ was added. The reaction mixture was stirred $2 \mathrm{~h}$ at $25{ }^{\circ} \mathrm{C}$. Solvents were removed under reduced pressure including three toluene co-evaporations to obtain compound 14 in a quantitative yield. ${ }^{1} \mathrm{H} \mathrm{NMR}(300 \mathrm{MHz}$, [D $\mathrm{D}_{6}$ ]DMSO): $\delta=8.16-7.96(\mathrm{~m}, 2 \mathrm{H}), 7.71(\mathrm{dd}, J=6.5,2.3 \mathrm{~Hz}, 1 \mathrm{H})$, 4.30 (s, $2 \mathrm{H}$ ) ppm. ${ }^{13} \mathrm{C} \mathrm{NMR}$ (75 MHz, [D 6 ]DMSO): $\delta=165.49,153.47$, 147.24, 138.91, 126.01, 123.85, 42.52 ppm. HRMS $\left(\mathrm{ESI}^{+}\right): \mathrm{m} / \mathrm{z}$ calcd. for $\mathrm{C}_{7} \mathrm{H}_{9} \mathrm{~N}_{2} \mathrm{O}_{2}[\mathrm{M}+\mathrm{H}]^{+}: 153.0659$ found 153.0651 .

Synthesis of Compound 15: An aqueous solution of $\mathrm{NaHCO}_{3}$ $(640 \mathrm{~mL}, 20 \% \mathrm{w} / \mathrm{vol})$ was added to a stirred solution of $14(19.6 \mathrm{~g}$, $73.7 \mathrm{mmol})$ in dioxane $(840 \mathrm{~mL})$ at $0{ }^{\circ} \mathrm{C}$. A solution of $\mathrm{Fmoc}-\mathrm{Cl}$ ( $20.0 \mathrm{~g}, 77.3 \mathrm{mmol}, 1.05$ equiv.) in dioxane $(150 \mathrm{~mL})$ was added dropwise. The reaction mixture was stirred $1 \mathrm{~h}$ at $0{ }^{\circ} \mathrm{C}$ then overnight at $25{ }^{\circ} \mathrm{C}$. Water was added followed by aqueous $\mathrm{HCl}(3 \mathrm{M}$, slow addition) to reach $\mathrm{pH} 3-4$. The precipitated compound was filtered, washed with water and $\mathrm{Et}_{2} \mathrm{O}$ to give a white powder. HPLC analysis indicated a purity of around $90 \%$ at this stage. The powder was suspended in $\mathrm{CH}_{2} \mathrm{Cl}_{2} / \mathrm{MeOH}$ (95:5 vol/vol) and the mixture was warmed to $40{ }^{\circ} \mathrm{C}$. Some soluble impurities were removed by filtration and the remaining undissolved product 15 was dried under vacuum $(17.1 \mathrm{~g}, 62 \%)$. HPLC purity of final product was $98 \% .{ }^{1} \mathrm{H}$ NMR (300 MHz, [D $\left.\left.\mathrm{D}_{6}\right] \mathrm{DMSO}\right): \delta=8.07(\mathrm{t}, \mathrm{J}=6.0 \mathrm{~Hz}, 1 \mathrm{H}), 7.88(\mathrm{~d}, \mathrm{~J}=$ $7.5 \mathrm{~Hz}, 2 \mathrm{H}), 7.84(\mathrm{~d}, J=7.7 \mathrm{~Hz}, 1 \mathrm{H}), 7.74(\mathrm{~d}, J=7.6 \mathrm{~Hz}, 1 \mathrm{H}), 7.70$ (d, J = 7.1 Hz, $2 \mathrm{H}), 7.41(\mathrm{t}, J=7.3 \mathrm{~Hz}, 2 \mathrm{H}), 7.31(\mathrm{t}, J=7.3 \mathrm{~Hz}, 2 \mathrm{H})$, $7.15(\mathrm{~d}, J=7.4 \mathrm{~Hz}, 1 \mathrm{H}), 4.36(\mathrm{~d}, J=6.7 \mathrm{~Hz}, 2 \mathrm{H}), 4.31(\mathrm{~d}, J=6.1 \mathrm{~Hz}$, $2 \mathrm{H}), 4.23(\mathrm{t}, \mathrm{J}=6.6 \mathrm{~Hz}, 1 \mathrm{H}) \mathrm{ppm} .{ }^{13} \mathrm{C} \mathrm{NMR}\left(75 \mathrm{MHz},\left[\mathrm{D}_{6}\right] \mathrm{DMSO}\right)$ : $\delta=168.25,157.77,156.66,156.28,143.89,140.77,137.30,127.63$, 127.11, 125.26, 122.23, 121.65, 120.11, 65.54, 46.81, 45.75 ppm. HRMS $\left(E S I^{+}\right): m / z$ calcd. for $\mathrm{C}_{22} \mathrm{H}_{19} \mathrm{~N}_{2} \mathrm{O}_{4}[\mathrm{M}+\mathrm{H}]^{+}: 375.1339$ found 375.1341. M.p. $183.5-185.4{ }^{\circ} \mathrm{C}$.

Synthesis of compound 16: To convert the P monomer in an acid chloride, a pre-activation as an $\mathrm{HCl}$ salt was carried out. Concentrated aqueous $\mathrm{HCl}$ ( $37 \%$ ) (1 equiv.) was added drop wise to compound 15 in $\mathrm{MeOH}$ and the mixture was stirred $30 \mathrm{~min}$ at $25^{\circ} \mathrm{C}$. The solvent was removed under reduced pressure, coevaporated thrice with toluene and thrice with $n$-hexane and further dried under vacuum for $1 \mathrm{~h}$. Ghosez reagent ( 3 equiv.) was added to the dried compound in dry $\mathrm{CH}_{2} \mathrm{Cl}_{2}$ under an $\mathrm{N}_{2}$ atmosphere and stirred for $1 \mathrm{~h}$. Volatiles were removed under vacuum and further dried for $2 \mathrm{~h}$ to obtain acid chloride 16, which was used in the coupling steps.

\section{Solid Phase Synthesis of Foldamers}

General Procedure for Solid Phase Synthesis: SPS of foldamers was carried out accordingly to reference 23. A low loading Wang resin with a loading of $0.38 \mathrm{mmol} \mathrm{g}^{-1}$ was used. For sequence having Phe at their C-terminus, the low-loading Wang resin was functionalized with Fmoc-Phe-OH using the well-documented anhydride method. ${ }^{[25]}$ For sequences having a $Q$ at their $\mathrm{C}$-terminus, the Wang resin was converted to a bromomethyl Wang resin to which the first $\mathrm{Q}$ monomer of each sequence was anchored in the presence of cesium iodide. ${ }^{[23]} \mathrm{Fmoc}$ deprotection was performed at room temperature with a $20 \mathrm{vol} .-\% / \mathrm{vol}$ solution of piperidine in DMF. When the main chain amine was an aromatic amine on a $Q$ unit, the subsequent monomer was introduced as an acid chloride produced by activation of the corresponding acids with the Ghosez reagent. Microwaves were applied during coupling $\left(50{ }^{\circ} \mathrm{C}, 50 \mathrm{~W}\right.$, for 5-15 min). Coupling completion on aromatic amines was confirmed with a modified DESC colorimetric test: a few resin beads were suspended in DMF. 5 drops of a $0.1 \mathrm{~m}$ solution of DESC in DMF and 2 drops of a 20 vol.-\%/vol solution of DIEA in DMF were added. The mixture was heated at $60{ }^{\circ} \mathrm{C}$ for $5 \mathrm{~min}$. The supernatant was re- 
moved and the beads washed with DMF. Clear beads correspond to a successful coupling. When the main chain amine was the aliphatic amine of a $P$ unit, the subsequent monomer was introduced using 3 equiv. of the $P$ or $Q$ monomer, HBTU ( 3 equiv.), DIEA ( 6 equiv.), microwave heating $\left(60{ }^{\circ} \mathrm{C}, 50 \mathrm{~W}, 10 \mathrm{~min}\right)$ repeating the process once. This method is cheaper than the PyBOP coupling described in reference $20 \mathrm{~b}$ which works as well. $\mathrm{N}$-terminal acetylation was carried out as described below. Introduction of the carbonic anhydrase inhibitor via a urea function was carried out as previously reported. ${ }^{[9 a]}$ Cleavage from the resin and deprotection of acid labile side chains was performed with a freshly prepared TFA solution containing triisopropylsilane (TIS) and water (TFA/TIS/ $\mathrm{H}_{2} \mathrm{O}, 95: 2.5: 2.5$ $\mathrm{vol} / \mathrm{vol} / \mathrm{vol})$. Crude purity was determined by RP-HPLC using the appropriate solvent system (typically a TFA-containing water/acetonitrile gradient).

$\mathbf{N}$-Terminal Acetylation. For P-Terminated Oligomers, this acetylation was carried out as described previously. ${ }^{[23]} \mathrm{N}$-terminal acetylation of Q-terminated oligomers was carried out as follows. After Fmoc removal, the resin was swollen in THF $(0.3 \mathrm{~mL} / 50 \mathrm{mg}$ resin). DIEA (6 equiv.) was added. Acetyl chloride ( 3 equiv.) was dissolved in dry THF and added to the resin. The solution was treated with microwaves $\left(50 \mathrm{~W}, 60{ }^{\circ} \mathrm{C}, 15 \mathrm{~min}\right.$ ) and the process repeated once. The resin was then washed thoroughly with $\mathrm{DMF}, \mathrm{CH}_{2} \mathrm{Cl}_{2}$ and $\mathrm{CH}_{2} \mathrm{Cl}_{2} / \mathrm{MeOH}, 1: 1$, then dried and desiccated under vacuum.

Compound 1: Crude compound was obtained in $94 \%$ purity. The compound was purified through HPLC purification; Gradient: 5$50 \%$ Solvent $B$ in solvent $A$ in $33 \mathrm{~min}$ (retention time $=13.6 \mathrm{~min}$ ). Purified Yield $=70 \% .{ }^{1} \mathrm{H}$ NMR $\left(400 \mathrm{MHz}, \mathrm{H}_{2} \mathrm{O} / \mathrm{D}_{2} \mathrm{O}, 9: 1 \mathrm{vol} / \mathrm{vol}\right): \delta=$ 10.49 (s, $1 \mathrm{H}), 9.77(\mathrm{~s}, 1 \mathrm{H}), 9.71(\mathrm{~s}, 1 \mathrm{H}), 7.98(\mathrm{~s}, 1 \mathrm{H}), 7.51-7.36(\mathrm{~m}$, $3 \mathrm{H}), 7.22-6.97(\mathrm{~m}, 4 \mathrm{H}), 6.92-5.72(\mathrm{~m}, 26 \mathrm{H}), 5.32(\mathrm{~s}, 1 \mathrm{H}), 2.80-1.91$ $(\mathrm{m}, 10 \mathrm{H}), 1.75-1.01(\mathrm{~m}, 12 \mathrm{H}), 0.49(\mathrm{~d}, J=18.1 \mathrm{~Hz}, 2 \mathrm{H})$ ppm. HRMS $\left(\mathrm{ESI}^{+}\right): \mathrm{m} / \mathrm{z}$ calcd. for $\mathrm{C}_{77} \mathrm{H}_{78} \mathrm{~N}_{17} \mathrm{O}_{13}[\mathrm{M}+\mathrm{H}]^{+}: 1448.5960$ found 1448.5988

Compound 2: Crude compound was obtained in $50 \%$ purity. The compound was purified through HPLC purification; Gradient: 10$40 \%$ Solvent $B$ in solvent $A$ in $23 \mathrm{~min}$ (retention time $=15.2 \mathrm{~min}$ ). Purified Yield $=15 \% .{ }^{1} \mathrm{H}$ NMR $\left(300 \mathrm{MHz},\left[\mathrm{D}_{6}\right] \mathrm{DMSO}\right): \delta=11.53(\mathrm{~s}$, $1 \mathrm{H}), 11.19(\mathrm{~s}, 1 \mathrm{H}), 11.13(\mathrm{~s}, 1 \mathrm{H}), 11.06(\mathrm{~s}, 1 \mathrm{H}), 10.72(\mathrm{~s}, 1 \mathrm{H}), 8.55$ $(\mathrm{s}, 1 \mathrm{H}), 8.37(\mathrm{~s}, 1 \mathrm{H}), 8.20(\mathrm{~s}, 3 \mathrm{H}), 8.14-7.61(\mathrm{~m}, 22 \mathrm{H}), 7.61-7.08(\mathrm{~m}$, $9 \mathrm{H}), 7.03(\mathrm{~d}, J=7.6 \mathrm{~Hz}, 1 \mathrm{H}), 6.99-6.77(\mathrm{~m}, 2 \mathrm{H}), 6.77-6.45(\mathrm{~m}, 5 \mathrm{H})$, $6.18(\mathrm{~s}, 1 \mathrm{H}), 4.66-3.92(\mathrm{~m}, 7 \mathrm{H}), 3.30-2.94(\mathrm{~m}, 6 \mathrm{H}), 2.46-1.99(\mathrm{~m}$, $11 \mathrm{H}), 1.52(\mathrm{~s}, 2 \mathrm{H})$ ppm. HRMS $\left(E S I^{+}\right): \mathrm{m} / \mathrm{z}$ calcd. for $\mathrm{C}_{97} \mathrm{H}_{97} \mathrm{~N}_{22} \mathrm{O}_{16}$ $[\mathrm{M}+\mathrm{H}]^{+}: 1825.7447$ found 1825.7448 .

Compound 3: Crude compound was obtained in $64 \%$ purity. The compound was purified through HPLC purification; Gradient: 10$40 \%$ Solvent $\mathrm{B}$ in $23 \mathrm{~min}$ ( $\mathrm{tr}=12.9 \mathrm{~min}$ ). Purified Yield $=18 \% .{ }^{1} \mathrm{H}$ NMR of the diastereomers mixture (85:15 ratio). The following ${ }^{1} \mathrm{H}$ NMR signals belong to both the minor and major diastereomers: (300 MHz, $\left.\mathrm{H}_{2} \mathrm{O} / \mathrm{D}_{2} \mathrm{O}, 9: 1 \mathrm{vol} / \mathrm{vol}\right): \delta=11.21(\mathrm{~s}, 1 \mathrm{H}), 11.12(\mathrm{~s}, 1 \mathrm{H})$, $11.00(\mathrm{~s}, 1 \mathrm{H}), 10.88(\mathrm{~s}, 1 \mathrm{H}), 10.82(\mathrm{~s}, 1 \mathrm{H}), 10.72(\mathrm{~s}, 1 \mathrm{H}), 10.48(\mathrm{~s}, 1$ $\mathrm{H}), 10.41(\mathrm{~s}, 1 \mathrm{H}), 10.00(\mathrm{~s}, 1 \mathrm{H}), 9.16(\mathrm{~s}, 1 \mathrm{H}), 8.98(\mathrm{~s}, 1 \mathrm{H}), 8.71(\mathrm{~s}, 1$ $\mathrm{H}), 8.52(\mathrm{~s}, 1 \mathrm{H}), 8.39(\mathrm{~s}, 1 \mathrm{H}), 8.27(\mathrm{~s}, 1 \mathrm{H}), 8.18-6.71(\mathrm{~m}, 38 \mathrm{H}), 6.62$ $(\mathrm{d}, J=7.8 \mathrm{~Hz}, 2 \mathrm{H}), 5.90(\mathrm{~s}, J=41.0 \mathrm{~Hz}, 2 \mathrm{H}), 3.88-2.83(\mathrm{~m}, 17 \mathrm{H})$, $2.58-2.13(\mathrm{~m}, 11 \mathrm{H}), 2.04-1.60(\mathrm{~m}, 3 \mathrm{H}), 1.60-1.19(\mathrm{~m}, 6 \mathrm{H}) \mathrm{ppm}$. HRMS $\left(\mathrm{ESI}^{+}\right): \mathrm{m} / \mathrm{z}$ calcd. for $\mathrm{C}_{117} \mathrm{H}_{116} \mathrm{~N}_{27} \mathrm{O}_{19}[\mathrm{M}+\mathrm{H}]^{+}: 2202.8935$ found 2202.8923 .

Compound 4: Crude compound was obtained in $85 \%$ purity. The compound was purified through HPLC purification; Gradient: 10$35 \%$ Solvent $B$ in solvent $A$ in $23 \mathrm{~min}$ (retention time $=19.4 \mathrm{~min}$ ). Purified Yield $=25 \%$. ${ }^{1} \mathrm{H}$ NMR $\left(300 \mathrm{MHz}, \mathrm{H}_{2} \mathrm{O} / \mathrm{D}_{2} \mathrm{O}, 9: 1 \mathrm{vol} / \mathrm{vol}\right): \delta=$ $11.23(\mathrm{~s}, 1 \mathrm{H}), 11.10$ (s, $1 \mathrm{H}), 11.02(\mathrm{~s}, 1 \mathrm{H}), 10.94(\mathrm{~s}, 1 \mathrm{H}), 10.83$ (s, 1
H), $10.73(\mathrm{~s}, 1 \mathrm{H}), 10.54(\mathrm{~s}, 1 \mathrm{H}), 10.33(\mathrm{~s}, 1 \mathrm{H}), 9.39-9.32(\mathrm{~m}, 1 \mathrm{H})$, 9.32-9.25 (m, $1 \mathrm{H}), 8.93(\mathrm{~s}, 1 \mathrm{H}), 8.88(\mathrm{~s}, 1 \mathrm{H}), 8.69-8.58(\mathrm{~m}, 1 \mathrm{H})$, 8.58-8.53 (m, $1 \mathrm{H}), 8.53-8.39(\mathrm{~m}, 3 \mathrm{H}), 8.18-8.02(\mathrm{~m}, 8 \mathrm{H}), 8.02-7.76$ (m, $24 \mathrm{H}), 7.76-7.07(\mathrm{~m}, 25 \mathrm{H}), 6.99(\mathrm{~d}, J=14.3 \mathrm{~Hz}, 5 \mathrm{H}), 6.70$ (dd, $J=39.9,31.8 \mathrm{~Hz}, 10 \mathrm{H}), 6.11(\mathrm{~s}, 1 \mathrm{H}), 6.06-5.67(\mathrm{~m}, 3 \mathrm{H}), 3.71-3.01$ $(\mathrm{m}, 10 \mathrm{H}), 2.71-2.06(\mathrm{~m}, 10 \mathrm{H}), 1.32-1.03(\mathrm{~m}, 3 \mathrm{H}) \mathrm{ppm}$. HRMS $\left(\mathrm{ESI}^{+}\right)$: $\mathrm{m} / \mathrm{z}$ calcd. for $\mathrm{C}_{130} \mathrm{H}_{129} \mathrm{~N}_{30} \mathrm{O}_{21}[\mathrm{M}+\mathrm{H}]^{+}: 2445.9943$ found 2446.0250 .

Compound 5: Crude compound was obtained in $60 \%$ purity. The compound was purified through HPLC purification; Gradient: 10$50 \%$ Solvent $B$ in solvent $A$ in $23 \mathrm{~min}$ (retention time $=11.3 \mathrm{~min}$ ). Purified Yield $=37 \% .{ }^{1} \mathrm{H}$ NMR $\left(400 \mathrm{MHz}, \mathrm{H}_{2} \mathrm{O} / \mathrm{D}_{2} \mathrm{O}, 9: 1 \mathrm{vol} / \mathrm{vol}\right): \delta=$ $10.10(\mathrm{~s}, 1 \mathrm{H}), 9.69(\mathrm{~s}, 1 \mathrm{H}), 9.59(\mathrm{~s}, 1 \mathrm{H}), 9.33(\mathrm{~s}, 1 \mathrm{H}), 7.51-7.16(\mathrm{~m}$, $2 \mathrm{H}), 7.16-6.68(\mathrm{~m}, 8 \mathrm{H}), 6.68-5.83(\mathrm{~m}, 25 \mathrm{H}), 5.83-5.58(\mathrm{~m}, 2 \mathrm{H})$, 5.58-5.14 (m, $2 \mathrm{H}), 2.64-1.91(\mathrm{~m}, 9 \mathrm{H}), 1.82-0.89(\mathrm{~m}, 12 \mathrm{H}) \mathrm{ppm}$. HRMS $\left(\mathrm{ESI}^{+}\right): \mathrm{m} / \mathrm{z}$ calcd. for $\mathrm{C}_{77} \mathrm{H}_{78} \mathrm{~N}_{17} \mathrm{O}_{13}[\mathrm{M}+\mathrm{H}]^{+}: 1448.5960$ found 1448.6005 .

Compound 6: Crude compound was purified through HPLC purification; Gradient: $5-30 \%$ Solvent $B$ in $25 \mathrm{~min}$ ( $\operatorname{tr}=4.9 \mathrm{~min}$ ). ${ }^{1} \mathrm{H}$ NMR (300 MHz, [D $\mathrm{D}_{6}$ ]DMSO): $\delta=11.41(\mathrm{~s}, 1 \mathrm{H}), 11.15(\mathrm{~s}, 1 \mathrm{H}), 11.10(\mathrm{~s}, 1$ H), $11.08(\mathrm{~s}, 1 \mathrm{H}), 10.85(\mathrm{~s}, 1 \mathrm{H}), 9.23(\mathrm{~s}, 1 \mathrm{H}), 8.78(\mathrm{~s}, 1 \mathrm{H}), 8.47(\mathrm{~s}, 5$ H), 8.36-8.16 (m, J = 8.4 Hz, $7 \mathrm{H}), 8.11(\mathrm{~s}, 6 \mathrm{H}), 8.06-7.92(\mathrm{~m}, 6 \mathrm{H})$, 7.89-7.79 (m, J = 14.4, 6.9 Hz, $4 \mathrm{H}), 7.78-7.60(\mathrm{~m}, 4 \mathrm{H}), 7.56-7.37$ $(\mathrm{m}, J=20.1,16.6,8.8 \mathrm{~Hz}, 5 \mathrm{H}), 7.31-7.07(\mathrm{~m}, 8 \mathrm{H}), 7.05-6.90(\mathrm{~m}, 2$ H), 6.84-6.42 (m, $6 \mathrm{H}), 6.16(\mathrm{~s}, 1 \mathrm{H}), 4.62(\mathrm{~s}, 3 \mathrm{H}), 4.44(\mathrm{~s}, 3 \mathrm{H}), 4.30$ (s, $2 \mathrm{H}), 4.19(\mathrm{~s}, 4 \mathrm{H}), 3.45-3.28(\mathrm{~m}, \mathrm{~J}=21.4 \mathrm{~Hz}, 5 \mathrm{H}), 2.49-2.39(\mathrm{~m}$, $J=7.1 \mathrm{~Hz}, 4 \mathrm{H}), 1.49(\mathrm{~s}, 1 \mathrm{H}), 1.41(\mathrm{~s}, 1 \mathrm{H}), 1.19(\mathrm{t}, J=7.3 \mathrm{~Hz}, 8 \mathrm{H})$ ppm. HRMS (ESI): $m / z$ calcd. for $\mathrm{C}_{97} \mathrm{H}_{99} \mathrm{~N}_{22} \mathrm{O}_{16}[\mathrm{M}+3 \mathrm{H}]^{3+}: 609.2531$ found 609.2564 .

Compound 7: Crude compound was obtained in $62 \%$ purity. The compound was purified through HPLC purification; Gradient: 10$40 \%$ solvent $B$ in solvent $A$ in 30 min. Purified Yield $=17 \% .{ }^{1} \mathrm{H}$ NMR (300 MHz, H O/D D, 9:1 vol/vol): $\delta=10.98$ (s, $1 \mathrm{H}), 10.95$ (s, 1 H), $10.32(\mathrm{~s}, 1 \mathrm{H}), 9.76(\mathrm{~s}, 1 \mathrm{H}), 9.68(\mathrm{~s}, 1 \mathrm{H}), 9.08(\mathrm{~s}, 1 \mathrm{H}), 8.64(\mathrm{~s}, 1$ H), 8.30-8.01 (m, $4 \mathrm{H}), 8.01-6.46(\mathrm{~m}, 50 \mathrm{H}), 6.31(\mathrm{~d}, J=7.8 \mathrm{~Hz}, 1 \mathrm{H})$, $6.17(\mathrm{~s}, 1 \mathrm{H}), 5.55(\mathrm{~s}, 1 \mathrm{H}), 3.85-3.54(\mathrm{~m}, 2 \mathrm{H}), 3.49-3.01(\mathrm{~m}, 13 \mathrm{H})$, 2.59-1.83 (m, $13 \mathrm{H}), 1.83-1.41(\mathrm{~m}, 4 \mathrm{H}), 1.41-0.98(\mathrm{~m}, 5 \mathrm{H}) \mathrm{ppm}$. HRMS $\left(\mathrm{ESI}^{+}\right): \mathrm{m} / \mathrm{z}$ calcd. for $\mathrm{C}_{124} \mathrm{H}_{122} \mathrm{~N}_{29} \mathrm{O}_{20}[\mathrm{M}+\mathrm{H}]^{+}: 2336.9415$ found 2336.9440 .

Compound 8: Crude compound was obtained in $48 \%$ purity. The compound was purified through HPLC purification; Gradient: 10$40 \%$ Solvent $B$ in solvent $A$ in $30 \mathrm{~min}$ (retention time $=18.2 \mathrm{~min}$ ). Purified Yield $=8 \% .{ }^{1} \mathrm{H}$ NMR $\left(300 \mathrm{MHz},\left[\mathrm{D}_{6}\right] \mathrm{DMSO}\right): \delta=11.26(\mathrm{~s}, 2$ H), $10.93(\mathrm{~s}, 2 \mathrm{H}), 10.36(\mathrm{~s}, 2 \mathrm{H}), 9.89(\mathrm{~s}, 1 \mathrm{H}), 9.35(\mathrm{~s}, 2 \mathrm{H}), 9.11(\mathrm{~s}, 4$ H), 8.35-8.15 (m, $13 \mathrm{H}), 8.12-7.85(\mathrm{~m}, 25 \mathrm{H}), 7.80-7.67(\mathrm{~m}, 8 \mathrm{H})$, 7.62-7.54 (m, $4 \mathrm{H}), 7.52-7.25(\mathrm{~m}, 15 \mathrm{H}), 7.24-7.13(\mathrm{~m}, 6 \mathrm{H}), 7.08-$ $6.92(m, 8 H), 6.89-6.76(m, 4 H), 6.75-6.52(m, 8 H), 6.41(s, 3 H)$, 4.64-3.87 (m, $10 \mathrm{H}), 2.38-2.03(\mathrm{~m}, 23 \mathrm{H}), 1.58(\mathrm{~s}, 4 \mathrm{H}) \mathrm{ppm}$. HRMS (ESI): $\mathrm{m} / \mathrm{z}$ calcd. for $\mathrm{C}_{157} \mathrm{H}_{157} \mathrm{~N}_{37} \mathrm{O}_{25}[\mathrm{M}+4 \mathrm{H}]^{4+}: 740.0532$ found 740.0588

Compound 18: Crude compound was obtained in around $90 \%$ purity. The compound was purified through HPLC purification; Gradient: $5-100 \%$ Solvent $B$ in solvent $A$ in $22.9 \mathrm{~min}$ at $1.5 \mathrm{~mL} / \mathrm{min}$ (retention time $=9.4 \mathrm{~min})$. Purified Yield $=44 \% .{ }^{1} \mathrm{H} \mathrm{NMR}(300 \mathrm{MHz}$, [D $\mathrm{D}_{6}$ DMSO): $\delta=13.03$ (br. s, $1 \mathrm{H}, \mathrm{COOH}$ ), 12.15 (br. s, $1 \mathrm{H}, \mathrm{COOH}$ ), 11.75 (s, $1 \mathrm{H}, \mathrm{OH}), 11.38(\mathrm{~s}, 1 \mathrm{H}), 11.29(\mathrm{~s}, 1 \mathrm{H}), 11.25(\mathrm{~s}, 1 \mathrm{H}), 10.99$ $(\mathrm{s}, 1 \mathrm{H}), 10.50(\mathrm{~s}, 1 \mathrm{H}), 9.12(\mathrm{t}, J=6.0 \mathrm{~Hz}, 1 \mathrm{H}), 8.90-8.83(\mathrm{~m}, 1 \mathrm{H})$, $8.56(\mathrm{~s}, 1 \mathrm{H}), 8.50-8.44(\mathrm{~m}, 1 \mathrm{H}), 8.30-8.23(\mathrm{~m}, 1 \mathrm{H}), 8.15-7.07(\mathrm{~m}$, $40 \mathrm{H}), 6.84-6.72(\mathrm{~m}, 2 \mathrm{H}), 6.68-6.53(\mathrm{~m}, 3 \mathrm{H}), 6.46(\mathrm{~s}, 1 \mathrm{H}), 6.20-6.12$ ( $\mathrm{m}, 1 \mathrm{H}), 6.03(\mathrm{~s}, 1 \mathrm{H}), 4.97-1.81(\mathrm{~m}, 31 \mathrm{H}), 1.52-1.13(\mathrm{~m}, 10 \mathrm{H}) \mathrm{ppm}$. HRMS $\left(\mathrm{ESI}^{+}\right): \mathrm{m} / \mathrm{z}$ calcd. for $\mathrm{C}_{114} \mathrm{H}_{105} \mathrm{~N}_{23} \mathrm{O}_{24} \mathrm{~S}[\mathrm{M}+2 \mathrm{H}]^{2+}: 1105.8706$ found 1105.8707 . 
Compound 19: Crude compound was obtained in around $90 \%$ purity. The compound was purified through HPLC purification; Gradient: 5-100\% Solvent $B$ in solvent $A$ in $22.9 \mathrm{~min}$ at $1.5 \mathrm{~mL} / \mathrm{min}$ (retention time $=9.0 \mathrm{~min}$ ). Purified Yield $=50 \% .{ }^{1} \mathrm{H} \mathrm{NMR}(300 \mathrm{MHz}$, [D $\mathrm{D}_{6}$ DMSO): $\delta=12.62$ (br. s, $1 \mathrm{H}, \mathrm{COOH}$ ), 12.13 (br. s, $1 \mathrm{H}, \mathrm{COOH}$ ), $11.75(\mathrm{~s}, 1 \mathrm{H}, \mathrm{OH}), 11.26(\mathrm{~s}, 1 \mathrm{H}), 11.22(\mathrm{~s}, 1 \mathrm{H}), 11.12(\mathrm{~s}, 1 \mathrm{H}), 10.84$ $(\mathrm{s}, 1 \mathrm{H}), 10.25(\mathrm{~s}, 1 \mathrm{H}), 10.21(\mathrm{~s}, 1 \mathrm{H}), 9.78(\mathrm{~s}, 1 \mathrm{H}), 9.22-9.12(\mathrm{~m}, 1$ H), 8.66-8.51 (m, $1 \mathrm{H}), 8.39-8.21(\mathrm{~m}, 1 \mathrm{H}), 8.15-6.62(\mathrm{~m}, 71 \mathrm{H}), 6.46-$ $6.34(\mathrm{~m}, 2 \mathrm{H}), 6.17-6.04(\mathrm{~m}, 1 \mathrm{H}), 5.79-5.72(\mathrm{~m}, 1 \mathrm{H}), 5.49-5.42(\mathrm{~m}$, $1 \mathrm{H}), \quad 4.78-1.08(\mathrm{~m}, 55 \mathrm{H}) \mathrm{ppm}$. HRMS $\left(\mathrm{ESI}^{+}\right): \mathrm{m} / \mathrm{z}$ calcd. for $\mathrm{C}_{165} \mathrm{H}_{149} \mathrm{~N}_{34} \mathrm{O}_{30} \mathrm{~S}_{2}[\mathrm{M}+3 \mathrm{H}]^{3+}: 1050.0201$ found 1050.0215 .

Compound 20: Crude compound was obtained in $40 \%$ purity. The compound was purified through HPLC purification; Gradient: 10$40 \%$ Solvent $B$ in $30 \mathrm{~min}$ (retention time $=10.7 \mathrm{~min}$ ). ${ }^{1} \mathrm{H} \mathrm{NMR}$ (300 MHz, [D $\mathrm{D}_{6}$ DMSO): $\delta=11.27(\mathrm{~s}, 1 \mathrm{H}), 11.18(\mathrm{~s}, 1 \mathrm{H}), 10.91(\mathrm{~s}, 1$ H), $10.89(\mathrm{~s}, 1 \mathrm{H}), 10.60(\mathrm{~s}, 1 \mathrm{H}), 10.24(\mathrm{~s}, 1 \mathrm{H}), 9.13(\mathrm{t}, J=5.7 \mathrm{~Hz}, 1$ H), 9.03-8.88 (m, $1 \mathrm{H}), 8.68(\mathrm{~s}, 1 \mathrm{H}), 8.62(\mathrm{~s}, 1 \mathrm{H}), 8.25-8.07(\mathrm{~m}, 3 \mathrm{H})$, 8.07-7.95 (m, $3 \mathrm{H}), 7.85(\mathrm{dd}, J=20.6,9.6 \mathrm{~Hz}, 8 \mathrm{H}), 7.77-7.51(\mathrm{~m}, 9$ $H), 7.51-7.22(m, 13 H), 7.22-7.04(m, 5 H), 7.04-6.97(m, 1 H), 6.94$ $(\mathrm{s}, 1 \mathrm{H}), 6.82(\mathrm{~d}, J=7.5 \mathrm{~Hz}, 1 \mathrm{H}), 6.77-6.68(\mathrm{~m}, 2 \mathrm{H}), 6.68-6.56(\mathrm{~m}, 2$ H), $6.50(\mathrm{~s}, 1 \mathrm{H}), 6.42(\mathrm{~d}, J=7.4 \mathrm{~Hz}, 1 \mathrm{H}), 6.36-6.21(\mathrm{~m}, 1 \mathrm{H}), 4.39$ (d, $J=5.6 \mathrm{~Hz}, 2 \mathrm{H}), 3.96-3.83(\mathrm{~m}, 4 \mathrm{H}), 3.83-3.60(\mathrm{~m}, 4 \mathrm{H}), 2.33-1.93$ $(\mathrm{m}, 6 \mathrm{H}), 1.77-1.41(\mathrm{~m}, 9 \mathrm{H}), 1.32-1.08(\mathrm{~m}, 11 \mathrm{H}), 1.01(\mathrm{~d}, J=6.6 \mathrm{~Hz}$, $6 \mathrm{H}), 0.94-0.72(\mathrm{~m}, 2 \mathrm{H}) \mathrm{ppm}$. HRMS (ESI): $\mathrm{m} / \mathrm{z}$ calcd. for $\mathrm{C}_{134} \mathrm{H}_{116} \mathrm{~N}_{26} \mathrm{O}_{29} \mathrm{~S}[\mathrm{M}+2 \mathrm{H}]^{2+}: 1292.4056$ found 1292.4174.

Determination of the Molar Extinction Coefficient $\varepsilon$ Per Quinoline Unit: Molar extinction coefficients are necessary to measure oligomer concentrations because simply weighing samples is subject to variations in the content of counterions (e.g. trifluoroacetate) and water after freeze drying. Sample concentration was first calibrated by NMR spectroscopy. Compound 1 was dissolved in [D $D_{6}$ DMSO $(500 \mu \mathrm{L})$ at a concentration of about $2 \mathrm{~m}_{\mathrm{M}}$ as measured by weighing a sample. To this, a concentrated solution of an internal standard-4-cyanopyridine-2-carboxylic acid-having an accurately determined concentration was added in such a way that its final concentration was exactly $2 \mathrm{~m}_{\mathrm{M}}$ in the NMR tube. The concentration of 1 could then be determined by comparison of its signal integrations to those of the internal standard (Figure 5). Care must be taken so that integration is accurate [e.g. careful shimming, ${ }^{13} \mathrm{C}$ carbon decoupling, sufficiently long relaxation delay (d1), baseline correction, phasing].

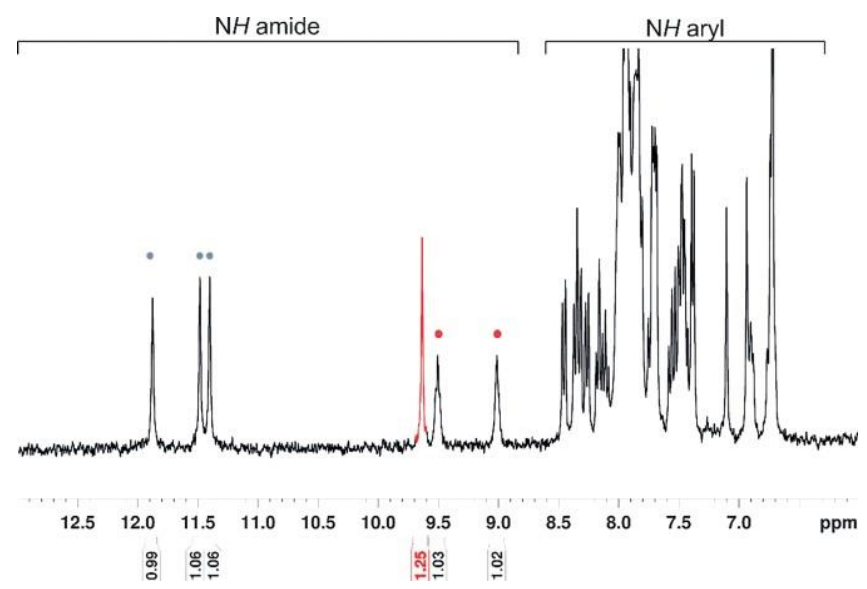

Figure 5. Excerpts of the ${ }^{1} \mathrm{H}$ NMR spectrum of compound 1 mixed with 4cyanopyridine-2-carboxylic acid (characteristic signal in red) at $2 \mathrm{~m}_{\mathrm{M}}$ in [D6]DMSO. Grey circles indicate $\mathrm{NH}$ resonances of quinoline amides, and red circles mark NH resonances of aminomethyl pyridines.
The stock solution of 1 whose exact concentration is now known was then used to prepare a series of diluted daughter solutions in DMSO whose UV absorbance was measured at $375 \mathrm{~nm}$ using a NanoDrop spectrophotometer. The data was used to generate a calibration curve (Figure 6), and to extract the extinction coefficient of 1 at $375 \mathrm{~nm}: \varepsilon=21370 \mathrm{~L} \mathrm{~mol}^{-1} \mathrm{~cm}^{-1}$. Since this foldamer has 4 quinolines, we have $\varepsilon / Q=5340 \mathrm{~L} \mathrm{~mol}^{-1} \mathrm{~cm}^{-1}$. This value was assumed to be sequence independent and extrapolated to measure the exact concentration of other foldamers in DMSO solutions according to the number of quinoline rings that they contain. DMSO stock solutions were diluted in aqueous buffers for CD measurements.

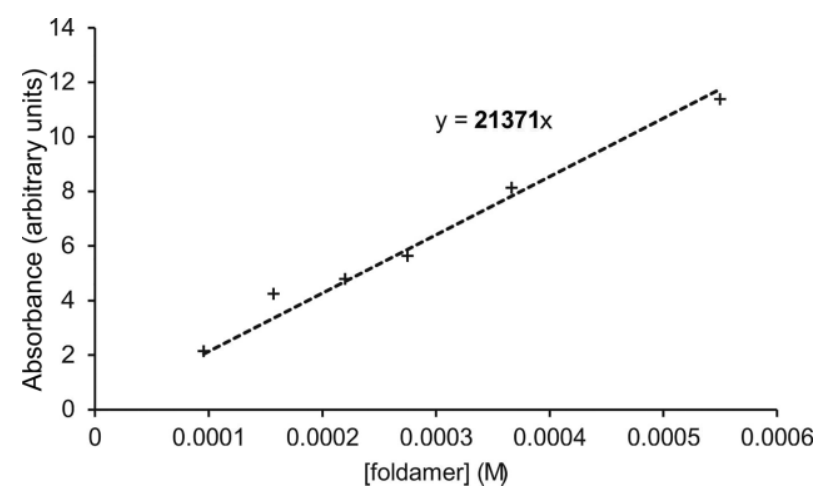

Figure 6. Calibration curve $A=f(c)$ giving the extinction coefficient of 1 at $375 \mathrm{~nm} 5340 \mathrm{~L} \mathrm{~mol}^{-1} \mathrm{~cm}^{-1} \mathrm{Q}^{-1}$.

Circular Dichroism (CD): CD spectra were recorded on a Jasco J815 Circular Dichroism spectrometer using quartz cells ( $2 \mathrm{~mm}$ op- tical path length). Scans were measured at $20^{\circ} \mathrm{C}$, over a wavelength range of $300-500 \mathrm{~nm}$, with a response time of $0.5 \mathrm{~s}$ and a scanning speed of $50 \mathrm{~nm} / \mathrm{min}$. The CD data represent an average of two scans after blank spectrum subtraction. Molar ellipticity values were normalized per quinoline residue.

CD Measurement for Kinetic Study: (Figure 3). Foldamers were first dissolved in DMSO (typically $300 \mu \mathrm{L}$ of a $35 \mu_{\mathrm{M}}$ solution) and the CD-spectra in DMSO were measured to validate handedness induction in this solvent as previously observed. ${ }^{[22]}$ Water was then added and the sample was freeze dried. This step was repeated twice to ensure the complete removal of DMSO. Foldamers were then incubated for $20 \mathrm{~min}$ in TFA $(50 \mu \mathrm{L})$. The absence of CD spectrum in this solvent was controlled at this stage. TFA was removed from the $C D$ cuvette by a gentle air flow followed by drying under vacuum. Buffered water ( $300 \mu \mathrm{L}, 12.5 \mathrm{~m}_{\mathrm{M}} \mathrm{NH}_{4} \mathrm{OAc}$ at $\mathrm{pH}=7.2$ ) was added and the evolution of $\mathrm{CD}$ spectrum over time was monitored at 22 or $37^{\circ} \mathrm{C}$.

CD Spectra of HCA-Foldamer Complexes: All CD were baselinecorrected for signal contributions due to the buffer containing HCAll (HCAll $34.5 \mu_{\mathrm{M}}$ in $50 \mathrm{~m}_{\mathrm{M}} \mathrm{NaH}_{2} \mathrm{PO}_{4}$ buffer at $\mathrm{pH}$ 7.4). Samples were prepared by adding 1 equiv. of the foldamer (dissolved in DMSO at a $10 \mathrm{~m}_{\mathrm{M}}$ concentration) to a solution containing HCAll $\left(34.5 \mu_{\mathrm{M}}\right)$ in a $50 \mathrm{~m}_{\mathrm{M}}$ aqueous $\mathrm{NaH}_{2} \mathrm{PO}_{4}$ buffer at $\mathrm{pH}$ 7.4 or 4.6. CD spectra were collected at different time intervals and checked after 1,3 and up to $8 d$ to confirm equilibrium has been reached.

\section{Acknowledgments}

This work was supported by the French Ministry of Education and Research (Pre-doctoral fellowship to M. V.) and the European Union (H2020- MSCA-IF-2016-751019 - PROFOLIG, post- 
doctoral fellowship to P. S. R.). It benefited from the facilities and expertise of the Biophysical and Structural Chemistry platform at IECB, CNRS UMS3033, INSERM US001, Bordeaux University, France. We thank Dr. S. Kwon and E. Merlet for assistance with the preparation and characterization of some compounds.

Keywords: Foldamers · Helical structures · Handedness inversion · Kinetics $\cdot$ Circular dichroism

[1] a) T. Nakano, Y. Okamoto, Chem. Rev. 2001, 101, 4013-4038; b) E. Yashima, K. Maeda, H. lida, Y. Furusho, K. Nagai, Chem. Rev. 2009, 109, 61026211 ; c) J. J. L. M. Cornelissen, A. E. Rowan, R. J. M. Nolte, N. A. J. M. Sommerdijk, Chem. Rev. 2001, 101, 4039-4070; d) E. Yashima, N. Ousaka, D. Taura, K. Shimomura, T. Ikai, K. Maeda, Chem. Rev. 2016, 116, 13752 13990.

[2] a) A. M. Abramyan, Z. Liu, V. Pophristic, Chem. Commun. 2015, 52, 669$672 ;$ b) N. Delsuc, T. Kawanami, J. Lefeuvre, A. Shundo, H. Ihara, M. Takafuji, I. Huc, ChemPhysChem 2008, 9, 1882-1890; c) S. Lifson, C. E. Felder, M. M. Green, Macromolecules 1992, 25, 4142-4148; d) M. Ohkita, J.-M. Lehn, G. Baum, D. Fenske, Chem. Eur. J. 1999, 5, 3471-3481.

[3] a) E. Yashima, T. Matsushima, Y. Okamoto, J. Am. Chem. Soc. 1995, 117, 11596-11597; b) K. Maeda, N. Yamamoto, Y. Okamoto, Macromolecules 1998, 31, 5924-5926; c) D. S. Schlitzer, B. M. Novak, J. Am. Chem. Soc. 1998, 120, 2196-2197; d) E. Yashima, K. Maeda, T. Yamanaka, J. Am. Chem. Soc. 2000, 122, 7813-7814; e) M. Ishikawa, K. Maeda, E. Yashima, J. Am. Chem. Soc. 2002, 124, 7448-7458; f ) E. Yashima, K. Maeda, O. Sato, J. Am. Chem. Soc. 2001, 123, 8159-8160; g) R. B. Prince, S. A. Barnes, J. S. Moore, J. Am. Chem. Soc. 2000, 122, 2758-2762; h) A. Tanatani, T. S. Hughes, J. S. Moore, Angew. Chem. Int. Ed. 2002, 41, 325-328; Angew. Chem. 2002, 114, 335-338; i) C. Li, G.-T. Wang, H.-P. Yi, X.-K. Jiang, Z.-T. Li, R.-X. Wang, Org. Lett. 2007, 9, 1797-1800; j) M. Inouye, M. Waki, H. Abe, J. Am. Chem. Soc. 2004, 126, 2022-2027; k) S. Takashima, H. Abe, M. Inouye, Chem. Commun. 2012, 48, 3330-3332; I) Y. Ferrand, A. M. Kendhale, B. Kauffmann, A. Grélard, C. Marie, V. Blot, M. Pipelier, D. Dubreuil, I. Huc, J. Am. Chem. Soc. 2010, 132, 7858-7859; m) N. Chandramouli, Y. Ferrand, G. Lautrette, B. Kauffmann, C. D. Mackereth, M. Laguerre, D. Dubreuil, I. Huc, Nat. Chem. 2015, 7, 334-341; n) H. Onouchi, T. Hasegawa, D. Kashiwagi, H. Ishiguro, K. Maeda, E. Yashima, J. Polym. Sci,, Part A J. Polym. Sci. A Polym. Chem. 2006, 44, 5039-5048; o) N. Ousaka, F. Mamiya, Y. Iwata, K. Nishimura, E. Yashima, Angew. Chem. Int. Ed. 2017, 56, 791-795; Angew. Chem. 2017, 129, 809-813.

[4] a) M. M. Green, J.-W. Park, T. Sato, A. Teramoto, S. Lifson, R. L. B. Selinger, J. V. Selinger, Angew. Chem. Int. Ed. 1999, 38, 3138-3154; Angew. Chem. $1999,111,3328-3345 ;$ b) M. M. Green, N. C. Peterson, T. Sato, A. Teramoto, R. Cook, S. Lifson, Science 1995, 268, 1860-1866.

[5] a) V. Maurizot, C. Dolain, I. Huc, Eur. J. Org. Chem. 2005, 1293-1301; b) N. Ousaka, Y. Inai, J. Org. Chem. 2009, 74, 1429-1439.

[6] a) R. A. Brown, V. Diemer, S. J. Webb, J. Clayden, Nat. Chem. 2013, 5, 853860; b) B. A. F. L. Bailly, J. Clayden, Chem. Commun. 2016, 52, 4852- 4863; c) K. Gratzer, V. Diemer, J. Clayden, Org. Biomol. Chem. 2017, 15, 35853589.

[7] a) E. Yashima, K. Maeda, Y. Okamoto, Nature 1999, 399, 449-451; b) K. Shimomura, T. Ikai, S. Kanoh, E. Yashima, K. Maeda, Nat. Chem. 2014, 6, 429-434; c) N. Ousaka, Y. Inai, R. Kuroda, J. Am. Chem. Soc. 2008, 130, 12266-12267.

[8] a) C. Dolain, H. Jiang, J.-M. Léger, P. Guionneau, I. Huc, J. Am. Chem. Soc. 2005, 127, 12943-12951; b) A. M. Kendhale, L. Poniman, Z. Dong, K. Laxmi-Reddy, B. Kauffmann, Y. Ferrand, I. Huc, J. Org. Chem. 2011, 76, 195200; c) M. Kudo, D. Carbajo López, V. Maurizot, H. Masu, A. Tanatani, I. Huc, Eur. J. Org. Chem. 2016, 2457-2466; d) Z. Liu, X. Hu, A. M. Abramyan, Á. Mészáros, M. Csékei, A. Kotschy, I. Huc, V. Pophristic, Chem. Eur. J. 2017, 23, 3605-3615.

[9] a) J. Buratto, C. Colombo, M. Stupfel, S. J. Dawson, C. Dolain, B. L. d'Estaintot, L. Fischer, T. Granier, M. Laguerre, B. Gallois, I. Huc, Angew. Chem. Int. Ed. 2014, 53, 883-887; Angew. Chem. 2014, 126, 902-906; b) M. Jewginski, L. Fischer, C. Colombo, I. Huc, C. D. Mackereth, ChemBioChem 2016, 17, 727-736; c) M. Jewginski, T. Granier, B. L. d'Estaintot, L. Fischer, C. D.
Mackereth, I. Huc, J. Am. Chem. Soc. 2017, 139, 2928-2931; d) K. Ziach, C. Chollet, V. Parissi, P. Prabhakaran, M. Marchivie, V. Corvaglia, P. P. Bose, K. Laxmi-Reddy, F. Godde, J.-M. Schmitter, S. Chaignepain, P. Pourquier, I. Huc, Nat. Chem. 2018, 10, 405-412.

[10] a) P. S. Shirude, E. R. Gillies, S. Ladame, F. Godde, K. Shin-ya, I. Huc, S. Balasubramanian, J. Am. Chem. Soc. 2007, 129, 11890-11891; b) P. K. Mandal, B. Baptiste, L. B. d'Estaintot, B. Kauffmann, I. Huc, ChemBioChem 2016, 17, 1911-1914.

[11] Yet the absence of bias does not imply that there is no interaction. It can also reflect equally strong interactions with the $P$ and $M$ helices.

[12] A. M. Watkins, M. G. Wuo, P. S. Arora, J. Am. Chem. Soc. 2015, 137, 1162211630.

[13] a) J. A. Kritzer, O. M. Stephens, D. A. Guarracino, S. K. Reznik, A. Schepartz, Bioorg. Med. Chem. 2005, 13, 11-16; b) D. Seebach, J. Gardiner, Acc. Chem. Res. 2008, 41, 1366-1375; c) J. D. Sadowsky, W. D. Fairlie, E. B. Hadley, H.-S. Lee, N. Umezawa, Z. Nikolovska-Coleska, S. Wang, D. C. S. Huang, Y.Tomita, S. H. Gellman, J. Am. Chem. Soc. 2007, 129, 139-154; d) L. Guo, A. M. Almeida, W. Zhang, A. G. Reidenbach, S. H. Choi, I. A. Guzei, S. H. Gellman, J. Am. Chem. Soc. 2010, 132, 7868-7869; e) Y. Imamura, N. Watanabe, N. Umezawa, T. Iwatsubo, N. Kato, T. Tomita, T. Higuchi, J. Am. Chem. Soc. 2009, 131, 7353-7359; f ) S. J. Shandler, I. V. Korendovych, D. T. Moore, K. B. Smith-Dupont, C. N. Streu, R. I. Litvinov, P. C. Billings, F. Gai, J. S. Bennett, W. F. DeGrado, J. Am. Chem. Soc. 2011, 133, 12378-12381; g) Y. Imamura, N. Umezawa, S. Osawa, N. Shimada, T. Higo, S. Yokoshima, T. Fukuyama, T. Iwatsubo, N. Kato, T. Tomita, T. Higuchi, J. Med. Chem. 2013, 56, 1443-1454; h) T. Sawada, S. H. Gellman, J. Am. Chem. Soc. 2011, 133, 7336-7339; i) J. T. Nguyen, C. W. Turck, F. E. Cohen, R. N. Zuckermann, W. A. Lim, Science 1998, 282, 2088-2092; j) L. Fischer, P. Claudon, N. Pendem, E. Miclet, C. Didierjean, E. Ennifar, G. Guichard, Angew. Chem. Int. Ed. 2010, 49, 1067-1070; Angew. Chem. 2010, 122, 10851088.

[14] a) B. P. Orner, J. T. Ernst, A. D. Hamilton, J. Am. Chem. Soc. 2001, 123, 53825383; b) J. T. Ernst, J. Becerril, H. S. Park, H. Yin, A. D. Hamilton, Angew. Chem. Int. Ed. 2003, 42, 535-539; Angew. Chem. 2003, 115, 553- 557; c) J. M. Rodriguez, A. D. Hamilton, Angew. Chem. Int. Ed. 2007, 46, 8614-8617; Angew. Chem. 2007, 119, 8768-8771; d) F. Campbell, J. P. Plante, T. A. Edwards, S. L. Warriner, A. J. Wilson, Org. Biomol. Chem. 2010, 8, 23442351; e) J.-M. Ahn, S.-Y. Han, Tetrahedron Lett. 2007, 48, 3543- 3547; f) A. Shaginian, L. R. Whitby, S. Hong, I. Hwang, B. Farooqi, M. Searcey, J. Chen, P. K. Vogt, D. L. Boger, J. Am. Chem. Soc. 2009, 131, 5564-5572.

[15] a) D. S. Kemp, Trends Biotechnol. 1990, 8, 249-255; b) W. Maison, E. Arce, P. Renold, R. J. Kennedy, D. S. Kemp, J. Am. Chem. Soc. 2001, 123, 1024510254; c) S. Hanessian, G. Papeo, K. Fettis, E. Therrien, M. T. P. Viet, J. Org. Chem. 2004, 69, 4891-4899; d) J. Fremaux, L. Mauran, K. Pulka-Ziach, B. Kauffmann, B. Odaert, G. Guichard, Angew. Chem. Int. Ed. 2015, 54, 98169820; Angew. Chem. 2015, 127, 9954-9958; e) J. Maury, B. A. F. L. Bailly, J. Raftery, J. Clayden, Chem. Commun. 2015, 51, 11802-11805.

[16] a) D. Wang, W. Liao, P. S. Arora, Angew. Chem. Int. Ed. 2005, 44, 65256529; Angew. Chem. 2005, 117, 6683-6687; b) A. Patgiri, A. L. Jochim, P. S. Arora, Acc. Chem. Res. 2008, 41, 1289-1300; c) E. Cabezas, A. C. Satterthwait, J. Am. Chem. Soc. 1999, 121, 3862-3875.

[17] a) C. E. Schafmeister, J. Po, G. L. Verdine, J. Am. Chem. Soc. 2000, 122, 5891-5892; b) E. N. Murage, G. Gao, A. Bisello, J.-M. Ahn, J. Med. Chem. 2010, 53, 6412-6420; c) H. Jo, N. Meinhardt, Y. Wu, S. Kulkarni, X. Hu, K. E. Low, P. L. Davies, W. F. DeGrado, D. C. Greenbaum, J. Am. Chem. Soc. 2012, 134, 17704-17713; d) A. M. Spokoyny, Y. Zou, J. J. Ling, H. Yu, Y.-S. Lin, B. L. Pentelute, J.Am. Chem. Soc. 2013, 135, 5946-5949; e) A. D. de Araujo, H. N. Hoang, W. M. Kok, F. Diness, P. Gupta, T. A. Hill, R. W. Driver, D. A. Price, S. Liras, D. P. Fairlie, Angew. Chem. Int. Ed. 2014, 53, 6965-6969; Angew. Chem. 2014, 126, 7085-7089.

[18] T. Qi, V. Maurizot, H. Noguchi, T. Charoenraks, B. Kauffmann, M. Takafuji, H. Ihara, I. Huc, Chem. Commun. 2012, 48, 6337-6339.

[19] L. K. Henchey, A. L. Jochim, P. S. Arora, Curr. Opin. Chem. Biol. 2008, 12, 692-697.

[20] a) D. Sánchez-García, B. Kauffmann, T. Kawanami, H. Ihara, M. Takafuji, M.H. Delville, I. Huc, J. Am. Chem. Soc. 2009, 131, 8642-8648; b) B. Bap- tiste, C. Douat-Casassus, K. Laxmi-Reddy, F. Godde, I. Huc, J. Org. Chem. 2010, 75, 7175-7185; c) J. M. Rogers, S. Kwon, S. J. Dawson, P. K. Mandal, H. Suga, I. Huc, Nat. Chem. 2018, 10, 405-412. 
[21] In principle, proteinogenic side chains could also be installed on $P$ units (see ref. ${ }^{[20 b]}$ ) and allow for a free positioning of $P$ and $Q$ units both carrying proteinogenic side chains along the sequence. However, the chemistry of $P$ units is less straightforward than that of $Q$ units. The designs reported here thus exploit proteinogenic side chains borne by $Q$ units on one face of the helix, and the flexibility borne by $P$ units on the other face.

[22] S. J. Dawson, Á. Mészáros, L. Pethő, C. Colombo, M. Csékei, A. Kotschy, I. Huc, Eur. J. Org. Chem. 2014, 4265-4275.
[23] S. J. Dawson, X. Hu, S. Claerhout, I. Huc, Meth. Enzymol. 2016, 580, 279301.

[24] C. Dolain, V. Maurizot, I. Huc, Angew. Chem. Int. Ed. 2003, 42, 2738-2740; Angew. Chem. 2003, 115, 2844-2846.

[25] W. Chan, P. White, Fmoc Solid Phase Peptide Synthesis: A Practical Approach. OUP Oxford: 2000. 